\title{
Carbon dioxide fluxes and carbon balance of an agricultural grassland in southern Finland
}

\author{
Laura Heimsch $^{1}$, Annalea Lohila ${ }^{1,2}$, Juha-Pekka Tuovinen ${ }^{1}$, Henriikka Vekuri ${ }^{1}$, Jussi Heinonsalo ${ }^{1,3}$, Olli Nevalainen ${ }^{1}$, \\ Mika Korkiakoski $^{1}$, Jari Liski ${ }^{1}$, Tuomas Laurila ${ }^{1}$, and Liisa Kulmala ${ }^{1,3}$ \\ ${ }^{1}$ Finnish Meteorological Institute, P.O. Box 503, 00101 Helsinki, Finland \\ ${ }^{2}$ Institute for Atmospheric and Earth System Research, Physics, University of Helsinki, \\ P.O. Box 64, 00014 University of Helsinki, Finland \\ ${ }^{3}$ Institute for Atmospheric and Earth System Research, Forest Sciences, University of Helsinki, \\ P.O. Box 27, 00014 University of Helsinki, Finland
}

Correspondence: Laura Heimsch (laura.heimsch@fmi.fi)

Received: 11 November 2020 - Discussion started: 30 November 2020

Revised: 29 April 2021 - Accepted: 9 May 2021 - Published: 10 June 2021

\begin{abstract}
A significant proportion of the global carbon emissions to the atmosphere originate from agriculture. Therefore, continuous long-term monitoring of $\mathrm{CO}_{2}$ fluxes is essential to understand the carbon dynamics and balances of different agricultural sites. Here we present results from a new eddy covariance flux measurement site located in southern Finland. We measured $\mathrm{CO}_{2}$ and $\mathrm{H}_{2} \mathrm{O}$ fluxes at this agricultural grassland site for 2 years, from May 2018 to May 2020. In particular the first summer experienced prolonged dry periods, which affected the $\mathrm{CO}_{2}$ fluxes, and substantially larger fluxes were observed in the second summer. During the dry summer, leaf area index (LAI) was notably lower than in the second summer. Water use efficiency increased with LAI in a similar manner in both years, but photosynthetic capacity per leaf area was lower during the dry summer. The annual carbon balance was calculated based on the $\mathrm{CO}_{2}$ fluxes and management measures, which included input of carbon as organic fertilizers and output as yield. The carbon balance of the field was $-57 \pm 10$ and $-86 \pm 12 \mathrm{~g} \mathrm{C} \mathrm{m}^{-2} \mathrm{yr}^{-1}$ in the first and second study years, respectively.
\end{abstract}

\section{Introduction}

Conventional and intensive agricultural practices cause significant carbon emissions while diminishing the soil organic matter (SOM) content. This leads to a reduction of soil quality and health (e.g. Houghton and Nassikas, 2017; Le Quéré et al., 2009, 2017; Lal, 2016; Paustian et al., 2000; Smith, 2008). Currently, agriculture is responsible for more than $10 \%$ of the global anthropogenic greenhouse gas (GHG) emissions to the atmosphere (Le Quéré et al., 2017). Soil type and properties, vegetation, climate, and weather conditions as well as management practices all have a considerable effect on the carbon fluxes and balances of agroecosystems (Bolinder et al., 2010; Gomez-Casanovas et al., 2012; Jensen et al., 2017; Lorenz and Lal, 2018; Singh et al., 2018). Frequent ploughing, monocropping and intensive use of agrochemicals are the main contributors to the loss of SOM and the resulting carbon dioxide $\left(\mathrm{CO}_{2}\right)$ emissions from land use (Ceschia et al., 2010; Reinsch et al., 2018; Yang et al., 2019). A change from conventional and intensive agricultural practices to regenerative and holistic farm management provides a substantial climate change mitigation potential (Lal, 2016). Increasing the amount of SOM in agroecosystems by applying enhanced management practices, such as lighter tillage, continuous plant cover, rotational grazing, agroforestry, increased biodiversity and cover cropping, would not only help to mitigate climate change but also to restore soil quality and fertility. In particular managed grasslands as part of agricultural systems have a high potential for substantial soil carbon sequestration (Soussana et al., 2010; Gilmanov et al., 2010; Yang et al., 2019). The importance of increasing soil organic carbon (SOC) content of agricultural soils has recently attained more attention, and the " 4 per mille Soils for Food Security and Climate" initiative was launched at the 
21 st Conference of the Parties to the United Nations Framework Convention on Climate Change in Paris in 2015 (Minasny et al., 2017). The aim of this initiative is to increase the soil carbon stock on all land surfaces in the upper $2 \mathrm{~m}$ on average by $0.4 \%$ annually. The possible increase in carbon content is largely dependent on the soil properties, e.g. clay content (Johannes et al., 2017; Minasny et al., 2017). This would be enough to sequester carbon from the atmosphere by an amount equivalent to the annual anthropogenic GHG emissions. However, the initiative states that the most potential SOC increases can be achieved on managed agricultural lands. In that case, the " 4 per 1000" means increasing SOC at the top $1 \mathrm{~m}$ layer of agricultural soils by $0.4 \%$ annually. That would effectively offset approximately $20 \%-35 \%$ of the global GHG emissions.

Agricultural ecosystems are highly prone to impacts of climate change, which induces a risk for food production. One of the possible impacts of climate change on agricultural ecosystems is associated with the changes in seasonal weather conditions and the resulting alteration in the carbon and water balance of these ecosystems (Ciais et al., 2014; Donnelly et al., 2017; Harrison et al., 2019). Severe drought events and storms causing considerable damage to agriculture have already been observed across Europe (Ciais et al., 2005; Wolf et al., 2013; Bastos et al., 2020). Moreover, adverse climatic impacts may be amplified by current and prior land use practices if they have not supported ecosystem resilience (Brunsell et al., 2014). For instance, a deeper root system is likely to buffer the negative impacts of climate variability. Also, high plant species diversity, compared to monocultures, favours the efficiency of plant water consumption and resilience to drought (De Boeck et al., 2006). As gross primary production (GPP) is closely related to ecosystem evapotranspiration (ET) via stomatal functions (Fricker and Willmer, 2012), changes in terrestrial water balance are potentially reflected in GPP and thus in the carbon balance of agricultural grasslands. The effect of water stress can be studied, for instance, by analysing ecosystem water use efficiency (WUE), i.e. the amount of carbon assimilated per unit of water lost by transpiration (Steduto, 1996). Generally, the productivity of a grassland ecosystem correlates with WUE, and thus ecosystems with a high productivity usually also have a high WUE (Hu et al., 2008). Environmental factors regulate WUE via effects on stomatal conductance and GPP, and during prolonged drought periods, for example, temperatureinduced downregulation of GPP may reduce WUE of grasslands in particular (Gharun et al., 2020). Furthermore, the WUE response depends on the intensity of the drought (Xu et al., 2019). However, the drought effects are also strongly related to season, as Wolf et al. (2013) reported that the WUE of Swiss grassland ecosystems did not respond to a spring drought and Bastos et al. (2020) concluded that the spring weather may either amplify or dampen the carbon and water dynamics during the following summer.
Better understanding of climatic impacts of agriculture and the effects of improved practices from the perspective of soil health and vitality is needed in order to develop tools for improved environmental management of these ecosystems. Continuous long-term measurements of the atmosphereecosystem fluxes are needed to identify the key factors affecting carbon dynamics of different ecosystems, to quantify the resulting carbon balance and its components, and to verify soil carbon and ecosystem models. Moreover, highquality GHG flux data are needed for a reliable, global measuring, reporting and verification system of agricultural carbon fluxes and soil carbon sequestration and stability (Smith et al., 2020).

The eddy covariance (EC) method is widely used for measuring $\mathrm{CO}_{2}$ and energy fluxes in different ecosystems and climatic conditions (Aubinet et al., 2012). The high-frequency measurements provided by EC allow a direct quantification and analysis of gas exchange between the ecosystem and atmosphere. The carbon balance calculated from EC data, combined with the additional carbon fluxes caused by management, serves as an important measure for determining the climatic impact of agricultural ecosystems (e.g. Baldocchi, 2003; Baldocchi et al., 2018). However, continuous GHG flux measurements on agricultural sites, especially on mineral soils and grasslands, are still scarce in the northern European countries (Shurpali et al., 2009; Lind et al., 2020; Jensen et al., 2017).

The aim of this study is to investigate, based on EC measurements, $\mathrm{CO}_{2}$ exchange between the atmosphere and a managed forage grassland in southern Finland. In particular, we had three specific research questions:

1. What is the magnitude of the annual carbon balance and its components?

2. Does the grass photosynthesis indicate occasional drought-related responses?

3. How does the possible carbon sink relate to the carbon sequestration objective of the " 4 per 1000 " initiative?

For the purposes of this study, we collected field data on the net exchange of $\mathrm{CO}_{2}$ and $\mathrm{H}_{2} \mathrm{O}$, soil and vegetation properties, and meteorological variables on an agricultural grassland in southern Finland for 2 years, from May 2018 to May 2020.

\section{Material and methods}

\subsection{Site description}

The flux measurements were conducted at the Qvidja farm in southern Finland $\left(60.29550^{\circ} \mathrm{N}, 22.39281^{\circ} \mathrm{E}\right.$; elevation $\left.5 \mathrm{~m}\right)$ from May 2018 to May 2020 (Fig. 1). The site belongs to the hemiboreal climate zone. From 1981 to 2010, the mean 
annual air temperature and precipitation at the Kaarina Yltöinen weather station, located $13 \mathrm{~km}$ northeast of Qvidja, were $5.4^{\circ} \mathrm{C}$ and $679 \mathrm{~mm}$, respectively (Pirinen et al., 2012). The experimental field in Qvidja has mineral soil (clay loam), and it covers 16.25 ha. It was cultivated as forage grassland during the study years. From 2008 to 2016, the field was managed intensively with conventional practices, and it was in annual crop rotation. In 2017, the field management practices were converted towards more sustainable and environmentally friendly farming by increasing the use of organic fertilizers and perennials, restricting the use of pesticides and increasing plant species biodiversity. The current grass and clover mixture was sown as an undergrown species with broad bean in spring 2017. The predominant species were timothy (Phleum pratense), meadow fescue (Festuca pratensis) and white clover (Trifolium repens).

Grass was harvested for silage for the first time on 12 June 2018. As the grass cover was fairly sparse later in the summer due to drought, oversowing was done on 3 September 2018 to restore the drought-induced damage. The seed mixture included $35 \%$ of timothy, $30 \%$ of rye grasses (Lolium spp.), $20 \%$ of common meadow grass (Poa pratensis) and $15 \%$ of red fescue (Festuca rubra). Timothy, meadow fescue and clover remained as the predominant species in 2019 and early 2020. On 21 August 2018, the grass was cut at approximately $15 \mathrm{~cm}$, but the yield was left in the field. The second harvest of 2018 occurred on 23 September. In 2019, the grass was harvested on 11 June and 20 August. In June 2018, a conventional cutting height of $6 \mathrm{~cm}$ was used, whereas in the other harvests the grass was cut at $15 \mathrm{~cm}$.

In 2018, the field was fertilized twice, on 16 July and 24 August, with 2800 and $1800 \mathrm{~kg} \mathrm{ha}^{-1}$ of NK-molasses, respectively (Table 1). NK-molasses is a byproduct of the sugar industry. It contained $67 \%$ of organic matter (OM) and $4.4 \%$ of nitrogen and had the $\mathrm{C}: \mathrm{N}$ ratio of 9 . According to the product information, the molasses included $205 \mathrm{~g} \mathrm{~kg}^{-1}$ of organic carbon. In addition, it contained potassium and small proportions of sulfur, magnesium, calcium and sodium.

In May 2019, the field was fertilized with a mixture of side products from industries of starch potato processing, biowaste processing and ethanol production out of sawdust. This fertilization mixture contained $70 \%$ (of dry weight) of OM, $1.3 \%$ of nitrogen, $0.2 \%$ of phosphorus, $3 \%$ of potassium and $0.4 \%$ of sulfur, as well as small amounts of calcium, magnesium, zinc, copper and manganese. Approximately $4600 \mathrm{~kg} \mathrm{ha}^{-1}$ was applied to the field on 8 May (Table 1). On 26 June after the first harvest, $220 \mathrm{~kg} \mathrm{ha}^{-1}$ of mineral fertilizers was applied. This fertilizer contained $23 \%$ of nitrogen, $10 \%$ of phosphorus and $8 \%$ of potassium.

\subsection{Measurement setup}

The $\mathrm{CO}_{2}$ and $\mathrm{H}_{2} \mathrm{O}$ fluxes were measured with the micrometeorological EC method. The flux measurements started on 3 May 2018, and here we analysed data collected from 4 May
2018 to 3 May 2020. From this point on, the periods of 4 May 2018-3 May 2019 and 4 May 2019-3 May 2020 are referred to as the first and second EC measurement years, respectively.

The EC instrumentation consisted of an enclosed infrared gas analyser (LI-7200, LI-COR Biosciences, NE, USA), which detects the $\mathrm{CO}_{2}$ and $\mathrm{H}_{2} \mathrm{O}$ mixing ratios, and a three-dimensional sonic anemometer (uSonic-3 Scientific, METEK GmbH, Elmshorn, Germany) to measure wind speed and air temperature. The data were recorded at $10 \mathrm{~Hz}$ frequency. The measurement height was $2.3 \mathrm{~m}$. The flow rate was about $12 \mathrm{~L} \mathrm{~min}^{-1}$, and the length of the $4 \mathrm{~mm}$ stainlesssteel inlet tube with $2 \mu \mathrm{m}$ Swagelok sinter was $0.8 \mathrm{~m}$. The $\mathrm{CO}_{2}$ measurements were regularly checked with zero and span gases, and the LI-7200 was recalibrated when necessary. The $\mathrm{H}_{2} \mathrm{O}$ measurements were compared with the data obtained from a dedicated humidity sensor; no recalibration was necessary.

The micrometeorological sign convention is used throughout the paper, with a negative value indicating the flux from the atmosphere to the ecosystem (net uptake) and a positive value indicating the flux from the ecosystem to the atmosphere (net emission).

Auxiliary meteorological measurements were conducted next to the flux tower. These included soil moisture observations at the depth of $0.1 \mathrm{~m}$ (ML3 ThetaProbe sensor, DeltaT Devices Ltd., Cambridge, UK) and soil temperature profiles at the depths of 5, 10 and $30 \mathrm{~cm}$ (Pt100 IKES sensors, Nokeval Oy, Nokia, Finland). The soil temperature data were collected with a Vaisala QML201C datalogger (Vaisala Oyj, Vantaa, Finland). Photosynthetically active radiation (PQS PAR sensor, Kipp \& Zonen B.V., Delft, the Netherlands), global and reflected solar radiation (CMP3 radiometer, Kipp \& Zonen), and air temperature and relative humidity (Humicap HMP155, Vaisala Oyj) were measured at the height of $1.8 \mathrm{~m}$. In addition, precipitation was measured with a weighing rain gauge (Pluvio2, OTT HydroMet GmbH, Kempten, Germany). Meteorological measurements started on 8 May 2018, and the data were recorded as $30 \mathrm{~min}$ averages, excluding the precipitation which was recorded as 1 min values. Snow depth was recorded at the weather station of Kaarina Yltöinen.

The leaf area index (LAI) data were obtained from the Sentinel-2 satellite as daily values on the clear-sky days. LAI was calculated from the Sentinel-2 bottom-of-atmosphere products (L2A) using the Google Earth Engine (GEE) and a Python implementation of the Biophysical Processor toolbox (Weiss and Baret, 2016) available in Sentinel Application Platform (SNAP) software. The cloudy, cloud-shadowed and snowy data were filtered out using the scene classification band available in the L2A products. 


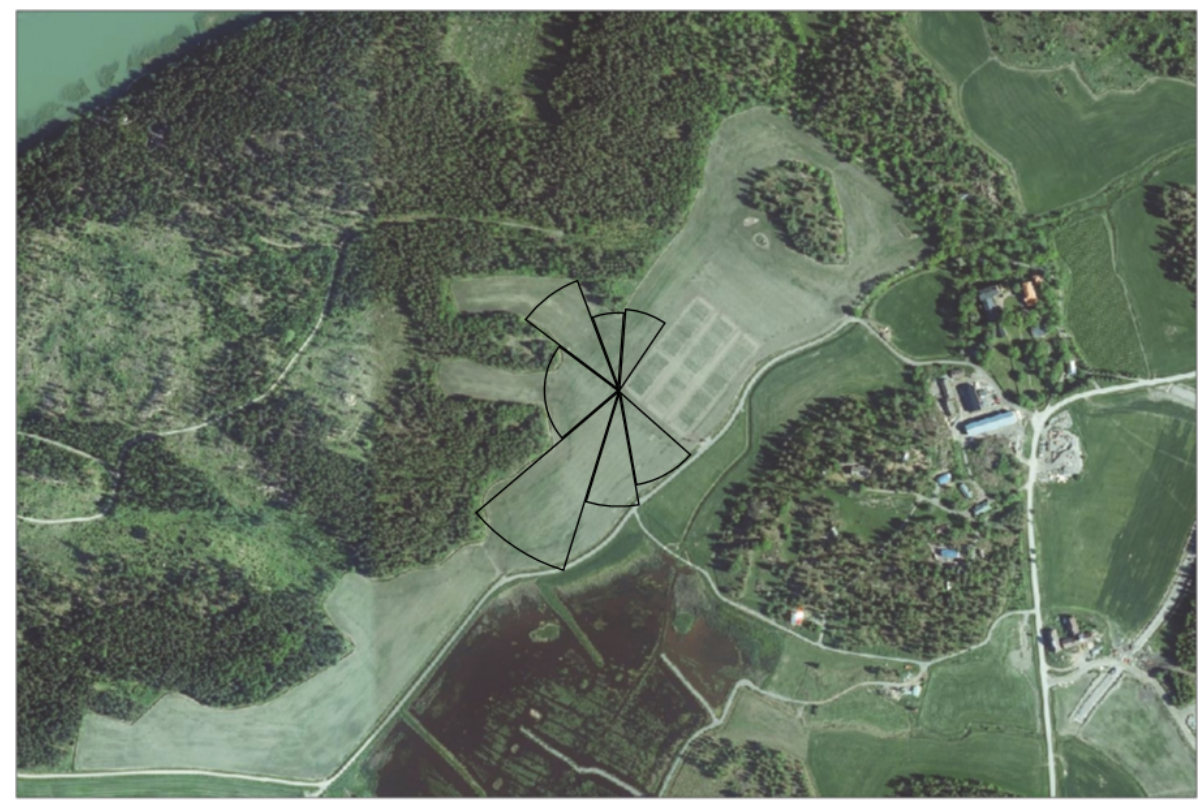

\llcorner

Figure 1. Experimental field with the sectors representing the target area that covers 3.9 ha. Eddy covariance tower is located in the centre of the sectors. EC data from wind directions from 30 to $140^{\circ}$ were discarded due to another experimental plot located in that part of the field. (Orthophoto from National Land Survey of Finland.)

Table 1. Different management events and their C inputs (fertilization) and C outputs (harvest). During the cutting in August 2018, the grass was not collected and thus did not result in any $\mathrm{C}$ flux allocated to management.

\begin{tabular}{llrrr}
\hline Date & Management & $\begin{array}{r}\text { Output } \\
(\text { dry weight kg ha }\end{array}$ & $\begin{array}{r}\text { Input } \\
\left(\mathrm{kg} \mathrm{ha}^{-1}\right)\end{array}$ & $\begin{array}{r}\text { Carbon } \\
\left(\mathrm{g} \mathrm{m}^{-2}\right)\end{array}$ \\
\hline 12 Jun 2018 & Harvest & 1985 & & 83 \\
16 Jul 2018 & Fertilization & & -2800 & -57 \\
21 Aug 2018 & Cutting & - & - & - \\
24 Aug 2018 & Fertilization & 348 & & -36 \\
23 Sep 2018 & Harvest & & -4606 & -43 \\
8 May 2019 & Fertilization & 3107 & & 130 \\
11 Jun 2019 & Harvest & - & - & - \\
20 Jun 2019 & Fertilization (mineral) & 1029 & & 43 \\
20 Aug 2019 & Harvest & & & \\
\hline
\end{tabular}

\subsection{Eddy covariance data processing}

The turbulent fluxes were determined as the covariance between the variations in vertical wind component and gas mixing ratio recorded at $10 \mathrm{~Hz}$. They were calculated as $30 \mathrm{~min}$ block averages applying standard procedures, including double coordinate rotation and lag determination based on crosscorrelation analysis (Rebmann et al., 2012). The systematic flux loss due to the incomplete frequency response of the measurement system was corrected according to the empirical method described by Laurila et al. (2005).

The EC data from 5 January to 28 March 2019 were affected by technical issues with an inlet filter, which resulted in an erroneous reading of the internal analyser pressure. For this period, the $10 \mathrm{~Hz}$ mixing ratios were recalculated from the recorded absorptance data using the instrument-specific calibration functions. The mean $\mathrm{CO}_{2}$ mixing ratio was set to $410 \mathrm{ppm}$ in these calculations.

The following acceptance criteria were applied to screen the $30 \mathrm{~min}$ averaged $\mathrm{CO}_{2}$ flux data: number of spikes in the raw data $<150$ of 18000 , relative stationarity of $\mathrm{CO}_{2}$ flux (Foken et al., 2012) $<50 \%$, mean $\mathrm{CO}_{2}$ mixing ratio $>380 \mathrm{ppm}$, variance of $\mathrm{CO}_{2}$ mixing ratio $<15 \mathrm{ppm}^{2}$ between April and September and $<5 \mathrm{ppm}^{2}$ between October and March, and wind direction within $0-30^{\circ}$ or $140-360^{\circ}$. Furthermore, the data were discarded during the periods of weak turbulence and when the flux footprint was not sufficiently representative of the target grassland, as estimated 
with the footprint model of Kormann and Meixner (2001). For these, we applied a friction velocity limit of $0.06 \mathrm{~m} \mathrm{~s}^{-1}$ and a cumulative footprint limit of 0.7 . The further screening applied to $\mathrm{H}_{2} \mathrm{O}$ fluxes included $\mathrm{H}_{2} \mathrm{O}$ flux $>0$, relative stationarity of $\mathrm{H}_{2} \mathrm{O}$ flux $<50 \%$ and variance of $\mathrm{H}_{2} \mathrm{O}$ mixing ratio $<1\left(\mathrm{mmol} \mathrm{mol}^{-1}\right)^{2}$. After applying these filtering criteria, the coverage of $\mathrm{CO}_{2}$ and $\mathrm{H}_{2} \mathrm{O}$ flux data accepted for further analysis was $44 \%$ and $30 \%$ of all the 30 min periods (i.e. total of 35088 time steps) during the 2 measurement years, respectively (for $\mathrm{CO}_{2}$, day/night $55 \% / 33 \%$, AprilSeptember/October-March $48 \% / 38 \%$; for $\mathrm{H}_{2} \mathrm{O}$, day/night $49 \% / 11 \%$, April-September/October-March $41 \% / 16 \%$ ). Most of the accepted $\mathrm{CO}_{2}$ and $\mathrm{H}_{2} \mathrm{O}$ flux data were collected when the wind direction was in the south-southwest sector (Fig. 2).

\subsection{Flux partitioning and gap-filling}

To calculate $\mathrm{CO}_{2}$ balances and to analyse the components of the net ecosystem exchange between the field and the atmosphere, the measured $\mathrm{CO}_{2}$ flux data (i.e. net ecosystem exchange, NEE) were partitioned to GPP and total ecosystem respiration $\left(R_{\text {eco }}\right)$ and gap-filled based on this partitioning:

$\mathrm{NEE}=\mathrm{GPP}+R_{\text {eco }}$.

The gap-filled GPP and $R_{\text {eco }}$ were calculated with empirical response functions by first fitting these functions to the flux data. $R_{\text {eco }}$ was expressed as a function of temperature (Lloyd and Taylor, 1994):

$R_{\mathrm{eco}}=R_{0} e^{E_{0}\left(\frac{1}{T_{1}}-\frac{1}{T_{\mathrm{a}}-T_{0}}\right)}$,

where $R_{0}$ is the respiration rate $\left(\mathrm{mg} \mathrm{m}^{-2} \mathrm{~s}^{-1}\right)$ at the reference temperature of $283.15 \mathrm{~K}, T_{0}=227.13 \mathrm{~K}, T_{1}=56.02 \mathrm{~K}$, $E_{0}$ is ecosystem sensitivity coefficient (Lloyd and Taylor, 1994) that describes the temperature response of soil respiration and $T_{\mathrm{a}}$ is the air temperature.

GPP was modelled as a function of photosynthetically active radiation (PAR, $\mu \mathrm{mol} \mathrm{m} \mathrm{m}^{-2} \mathrm{~s}^{-1}$ ) as

$\mathrm{GPP}=\frac{\alpha \times \mathrm{PAR} \times \mathrm{GP}_{\max }}{\alpha \times \mathrm{PAR}+\mathrm{GP}_{\max }}$,

where $\alpha$ is the apparent quantum yield $\left(\mathrm{mg} \mathrm{mol}^{-1}\right)$, and $\mathrm{GP}_{\max }$ denotes the asymptotic $\mathrm{CO}_{2}$ uptake rate in optimal light conditions $\left(\mathrm{mg} \mathrm{m}^{-2} \mathrm{~s}^{-1}\right)$. Further details on the gapfilling procedure are provided in Appendix A. Energy fluxes were gap-filled following the description in Appendix B.

To study the differences in photosynthetic capacity of the grass field between the two growing seasons, daily $\mathrm{GP}_{1200}$ values were calculated with the estimated $\alpha$ and $\mathrm{GP}_{\max }$ values; i.e. GPP was normalized to PAR $=1200 \mu \mathrm{mol} \mathrm{m}^{-2} \mathrm{~s}^{-1}$.

\subsection{Net ecosystem carbon balance}

In this study, the system boundaries include the main components of the carbon balance of the field ecosystem studied.
The carbon balance was calculated by adding up the $30 \mathrm{~min}$ NEE fluxes, the imported carbon in the form of organic fertilizers and the carbon removed as harvested biomass:

$C_{\text {balance }}=C_{\mathrm{H}}+C_{\mathrm{F}}+\sum_{i=1}^{n} \mathrm{NEE}_{i}$,

where $C_{\mathrm{H}}$ is the amount of carbon in harvested biomass, $C_{\mathrm{F}}$ is the amount of carbon in imported fertilization and $n$ is the total number of time steps in the period for which the balance was calculated. Thus, the carbon balance indicates the net ecosystem carbon balance as defined by Chapin et al. (2006) without the contribution of carbon monoxide, methane, volatile organic and particulate compounds, or leaching. This balance is commonly called the net biome production (Kutsch et al., 2010). Biomass was converted to carbon by multiplying the dry weight by 0.42 (Lohila et al., 2004). The following sign convention was used: the carbon imported into the ecosystem corresponds to a negative flux, and the carbon removed from the system corresponds to a positive flux.

\subsection{Uncertainty analysis}

The $\mathrm{CO}_{2}$ balance between the field and the atmosphere, which is calculated based on the EC measurements, includes multiple potential error sources. Uncertainties are associated, for example, with the stochastic nature of turbulence and incomplete sampling of large eddies, the performance of instruments and the flux variation caused by the limited area of the target ecosystem (Aubinet et al., 2012). The most relevant random error sources, i.e. the statistical measurement error $\left(E_{\text {meas }}\right)$ and the error caused by gap-filling $\left(E_{\text {gap }}\right)(\mathrm{Au}-$ rela et al., 2002), were included in the uncertainty estimate:

$E_{\text {meas }}=\sqrt{\sum_{i=1}^{n}\left(\mathrm{NEE}_{\text {meas }, i}-\mathrm{NEE}_{\text {mod }, i}\right)^{2}}$,

where $\mathrm{NEE}_{\text {meas }}$ is the filtered 30 min flux, $\mathrm{NEE}_{\text {mod }}$ is the corresponding modelled NEE (Eqs. 1-3) and $n$ is the number of measured data.

$E_{\text {gap }}=\sqrt{\sum_{i=1}^{N}\left(E_{\mathrm{GPP}, i}^{2}+E_{R_{\text {eco }, i}}^{2}\right)}$,

where $E_{\mathrm{GPP}}$ and $E_{R_{\mathrm{eco}}}$ are the errors of modelled GPP and $R_{\text {eco }}$, respectively. $N$ is the number of gaps in the data.

The standard error propagation principle was used in estimating the total uncertainty $\left(E_{\mathrm{tot}}\right)$ of the annual carbon balance:

$E_{\mathrm{tot}}=\sqrt{E_{\text {meas }}^{2}+E_{\mathrm{gap}}^{2}}$. 

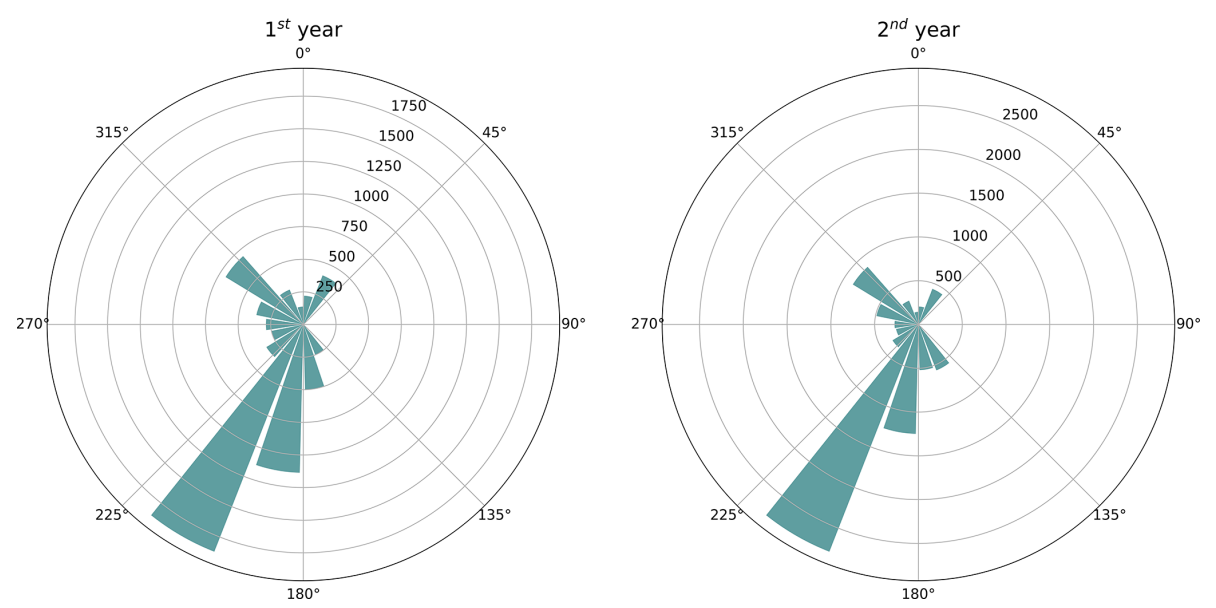

Figure 2. Number of accepted flux measurements within $20^{\circ}$ sectors around the flux tower during the first and second years. Data from 30 to $140^{\circ}$ were discarded.

\subsection{Water use efficiency}

The ecosystem WUE was defined as the ratio of GPP to ET, i.e. $\mathrm{H}_{2} \mathrm{O}$ flux:

$\mathrm{WUE}=\frac{\mathrm{GPP}}{\mathrm{ET}}$,

where daily means of GPP and ET were used. The ET data corresponding to a latent heat flux lower than $30 \mathrm{~W} \mathrm{~m}^{-2}$ were discarded (Abraha et al., 2016). Furthermore, days with precipitation were eliminated in order to obtain a signal that is dominated by transpiration.

\subsection{Soil carbon storage}

Soil carbon content was determined from $1 \mathrm{~m}$ deep core samples taken within the flux source area. The samples were taken in October 2018 using a hydraulic corer installed on a tractor. The diameter of the sample cylinder was $151 \mathrm{~mm}$. Subsamples were taken along the $1 \mathrm{~m}$ core at 16 points, and soil organic carbon (SOC, $\mathrm{kg} \mathrm{m}^{-2}$ ) content in each subsample was analysed using a VarioMax CN analyser (Elementar Analysensysteme GmbH, Germany).

\section{Results}

\subsection{Meteorological conditions}

The annual mean air temperature at the study site was 7.6 and $7.7^{\circ} \mathrm{C}$ in the first and second measurement years, respectively. Both years were warm compared to the long-term (1981-2010) average of $5.4^{\circ} \mathrm{C}$ measured at a nearby weather station (Pirinen et al., 2012). The annual precipitation sum was lower in the first year $(473 \mathrm{~mm})$ and higher in the second year $(855 \mathrm{~mm})$ than the long-time average $(679 \mathrm{~mm})$.

The thermal growing season, defined here as the period when the daily mean temperature permanently exceeded $5^{\circ} \mathrm{C}$, started on 14 April in 2018, i.e. before the EC measurements started. In 2019 and 2020, the thermal growing season began on 16 and 18 April, respectively. The thermal growing season ended on 17 November and 26 October in 2018 and 2019, respectively. Thus, the thermal growing season length was $218 \mathrm{~d}$ in 2018 and $194 \mathrm{~d}$ in 2019. Meteorological conditions during the main growing season between May and September varied substantially between the 2 years. The mean air temperature during these periods was 16.7 and $14.5^{\circ} \mathrm{C}$ in 2018 and 2019 , respectively. During the same period, the mean daily PAR was about $12 \%$ higher in 2018 than in 2019 ( 460 vs. $410 \mu \mathrm{mol} \mathrm{m}^{-2} \mathrm{~s}^{-1}$ ), while the precipitation sum was $32 \%$ lower (212 vs. $312 \mathrm{~mm})$.

During winter 2018-2019, permanent snow cover was recorded from 17 December 2018 to 26 March 2019. In the following winter (2019-2020), there were only two short snow-cover periods: 5-8 February and 30-31 March 2020. The maximum snow depth in the first winter was $33 \mathrm{~cm}$, whereas in the second winter it was $3 \mathrm{~cm}$. The mean wintertime (November-March) air temperature was $-0.2{ }^{\circ} \mathrm{C}$ in 2018-2019 and $2.2^{\circ} \mathrm{C}$ in 2019-2020.

Soil moisture content at the depth of $10 \mathrm{~cm}$ varied between 0.16 and $0.55 \mathrm{~m}^{3} \mathrm{~m}^{-3}$ during the study period. On several occasions, the daily mean soil moisture dropped to about $0.2 \mathrm{~m}^{3} \mathrm{~m}^{-3}$. During the growing seasons, such low values indicate substantial drought, while in the winter, rapid data drops were likely related to soil freezing. The average soil moisture during the growing season in 2019 was higher than in $2018\left(0.30\right.$ vs. $\left.0.26 \mathrm{~m}^{3} \mathrm{~m}^{-3}\right)$. As a result of the higher precipitation in 2019, soil moisture occasionally increased up to $0.4 \mathrm{~m}^{3} \mathrm{~m}^{-3}$, i.e. close to the saturated values observed in winter. 


\section{2 $\mathrm{CO}_{2}$ and $\mathrm{H}_{2} \mathrm{O}$ fluxes}

At the beginning of the measurements, the net $\mathrm{CO}_{2}$ fluxes were negative (Fig. 3), and the air temperature was already well above $10^{\circ} \mathrm{C}$ (Fig. 4). Net uptake was observed until the first harvest around mid-June 2018. This harvest and the following management events during that growing season induced large short-term variations in the $\mathrm{CO}_{2}$ fluxes. Similarly, in the second study year, large impacts on $\mathrm{CO}_{2}$ fluxes were observed after the management events. During the growing season, the mean NEE was -0.13 and $-0.21 \mathrm{mg} \mathrm{CO}_{2} \mathrm{~m}^{-2} \mathrm{~s}^{-1}$ in 2018 and 2019, respectively. During the wintertime, no significant $\mathrm{CO}_{2}$ uptake occurred, and the positive fluxes were small compared to the nocturnal fluxes in summer. The mean measured NEE between December 2018 and February 2019 was $0.03 \mathrm{mg} \mathrm{CO}_{2} \mathrm{~m}^{-2} \mathrm{~s}^{-1}$, and during the same period in 20192020 it was $0.04 \mathrm{mg} \mathrm{CO}_{2} \mathrm{~m}^{-2} \mathrm{~s}^{-1}$.

Seasonal patterns were also observed in the $\mathrm{H}_{2} \mathrm{O}$ fluxes (Fig. 3). In the spring, the ecosystem ET started to increase, reaching the highest levels between June and August, after which it gradually decreased to wintertime values, i.e. close to zero. The mean growing season $\mathrm{H}_{2} \mathrm{O}$ flux was $34.7 \mathrm{mg} \mathrm{H}_{2} \mathrm{O} \mathrm{m}^{-2} \mathrm{~s}^{-1}$ in 2018 and $35.5 \mathrm{mg} \mathrm{H}_{2} \mathrm{O} \mathrm{m}^{-2} \mathrm{~s}^{-1}$ in 2019. The wintertime (December-February) mean $\mathrm{H}_{2} \mathrm{O}$ flux was 3.6 and $3.7 \mathrm{mg} \mathrm{H}_{2} \mathrm{O} \mathrm{m}^{-2}$ in 2018-2019 and 2019-2020, respectively.

The experimental field was harvested and fertilized twice during each of the studied growing seasons (Table 1). The effect of management was investigated by comparing the mean fluxes $5 \mathrm{~d}$ before and after the harvest dates (Table C1). The harvest in June 2018 changed the mean $\mathrm{CO}_{2}$ flux from a net sink of $-0.28 \mathrm{mg} \mathrm{CO}_{2} \mathrm{~m}^{-2} \mathrm{~s}^{-1}$ to a source of $0.03 \mathrm{mgCO}_{2} \mathrm{~m}^{-2} \mathrm{~s}^{-1}$, i.e. increased the net efflux by $0.31 \mathrm{mg} \mathrm{CO}_{2} \mathrm{~m}^{-2} \mathrm{~s}^{-1}$. The first harvest of 2019 increased NEE by $0.47 \mathrm{mgCO}_{2} \mathrm{~m}^{-2} \mathrm{~s}^{-1}$, but as the preharvest mean NEE was $-0.50 \mathrm{mg} \mathrm{CO}_{2} \mathrm{~m}^{-2} \mathrm{~s}^{-1}$, the field remained as a net sink. As a result of the second harvest on 23 September 2018, the mean sink decreased from -0.10 to $-0.02 \mathrm{mg} \mathrm{CO}_{2} \mathrm{~m}^{-2} \mathrm{~s}^{-1}$, while the harvest on 20 August 2019 caused the sink to change from -0.25 to $-0.02 \mathrm{mg} \mathrm{CO}_{2} \mathrm{~m}^{-2} \mathrm{~s}^{-1}$. Thus, after all the harvests with a cutting height of $15 \mathrm{~cm}$, the mean sink rate was diminished to -0.02 or $-0.03 \mathrm{mg} \mathrm{CO}_{2} \mathrm{~m}^{-2} \mathrm{~s}^{-1}$.

In the first growing season, the first and second fertilization events with organic substances increased NEE by 0.27 and $0.08 \mathrm{mg} \mathrm{CO}_{2} \mathrm{~m}^{-2} \mathrm{~s}^{-1}$, respectively, i.e. diminished the $\mathrm{CO}_{2}$ sink (Fig. 3, Table C1). During the $5 \mathrm{~d}$ after the harvest in May 2019, the field acted as a $\mathrm{CO}_{2}$ source. A similar trend was not observed in June 2019, as mineral fertilizer was used, and thus no organic substances were added to the soil. Each of the fertilization events were followed by rain within the next $5 \mathrm{~d}$. However, the mean soil moisture at the depth of $10 \mathrm{~cm}$ either remained the same or decreased slightly (Fig. 4, Table C1). Furthermore, the mean air temperature increased after the fertilizations in July 2018 and May 2019, potentially affecting $\mathrm{CO}_{2}$ fluxes. After the fertilization events with organic substances in July 2018, August 2018 and May 2019, the mean PAR was $7 \%, 29 \%$ and $12 \%$ lower, respectively, than the $5 \mathrm{~d}$ mean before the fertilization, complicating the interpretation of fertilization impacts on the $\mathrm{CO}_{2}$ fluxes. The effect of management on $\mathrm{H}_{2} \mathrm{O}$ fluxes could not be disentangled from the present data (Fig. 3b).

The LAI derived from Sentinel-2 images (Fig. 4d) varied greatly between the years. The higher LAI in 2019 indicated that there was more photosynthesizing green biomass before the first and second harvests compared to 2018. The effect of larger leaf area was also observed in the differences in the photosynthetic capacity $\left(\mathrm{GP}_{1200}\right)$ of the grassland between the study years (Fig. 5a). The years differed significantly $(p<0.05)$ in terms of $\mathrm{GP}_{1200}$ at all levels of LAI $(>1)$. Larger LAI values were observed throughout 2019, indicating that grass was growing better than in 2018. Furthermore, the grassland was photosynthesizing more efficiently with the same leaf area in 2019 than in the previous year (Fig. 5a).

\subsection{Water use efficiency}

The ecosystem WUE estimate showed different seasonal variation during the studied growing seasons (Fig. 6). Generally, WUE was higher in 2019 than in 2018 throughout the growing season. WUE increased before the first harvest around mid-June in both years, indicating more efficient $\mathrm{CO}_{2}$ uptake in terms of water use than during the spring. The $5 \mathrm{~d}$ mean WUE before the first harvest was 2.8 and $3.0 \mathrm{~g} \mathrm{CO}_{2}\left(\mathrm{~kg} \mathrm{H}_{2} \mathrm{O}\right)^{-1}$ in 2018 and 2019, respectively. Due to the harvest, it dropped to $0.9 \mathrm{~g} \mathrm{CO}_{2}\left(\mathrm{~kg} \mathrm{H}_{2} \mathrm{O}\right)^{-1}$ in 2018 and to $2.6 \mathrm{~g} \mathrm{CO}_{2}\left(\mathrm{~kg} \mathrm{H}_{2} \mathrm{O}\right)^{-1}$ in 2019. During the latter growing season, WUE increased steadily towards $4 \mathrm{~g} \mathrm{CO}_{2}$ $\left(\mathrm{kg} \mathrm{H}_{2} \mathrm{O}\right)^{-1}$ until the second harvest in August, whereas in 2018 it remained predominantly below $2 \mathrm{~g} \mathrm{CO}_{2}\left(\mathrm{~kg} \mathrm{H}_{2} \mathrm{O}\right)^{-1}$ during the same period. At the end of August and early September, WUE was at the same level in both years.

The LAI derived from the Sentinel-2 data was compared to the daily WUE values (Fig. 5b) to further cast light on the relationship between vegetation status and WUE. While WUE was on average lower in 2018 than 2019, the difference at a given LAI was not significant $(p>0.05)$. However, in both years the daily WUE increased in a similarly linear manner in relation to LAI.

\subsection{Carbon balance and soil carbon storage}

The carbon balance of the studied grass field was $-57 \pm 10 \mathrm{~g} \mathrm{C} \mathrm{m}^{-2} \mathrm{yr}^{-1}$ in the first year, and the balance of the second year was $-86 \pm 12 \mathrm{~g} \mathrm{Cm}^{-2} \mathrm{yr}^{-1}$, i.e. the field acted as a net carbon sink in both years (Table 2). The magnitude of all components of the carbon balance were smaller in the first year than in the second one, GPP by $29 \%, R_{\text {eco }}$ 

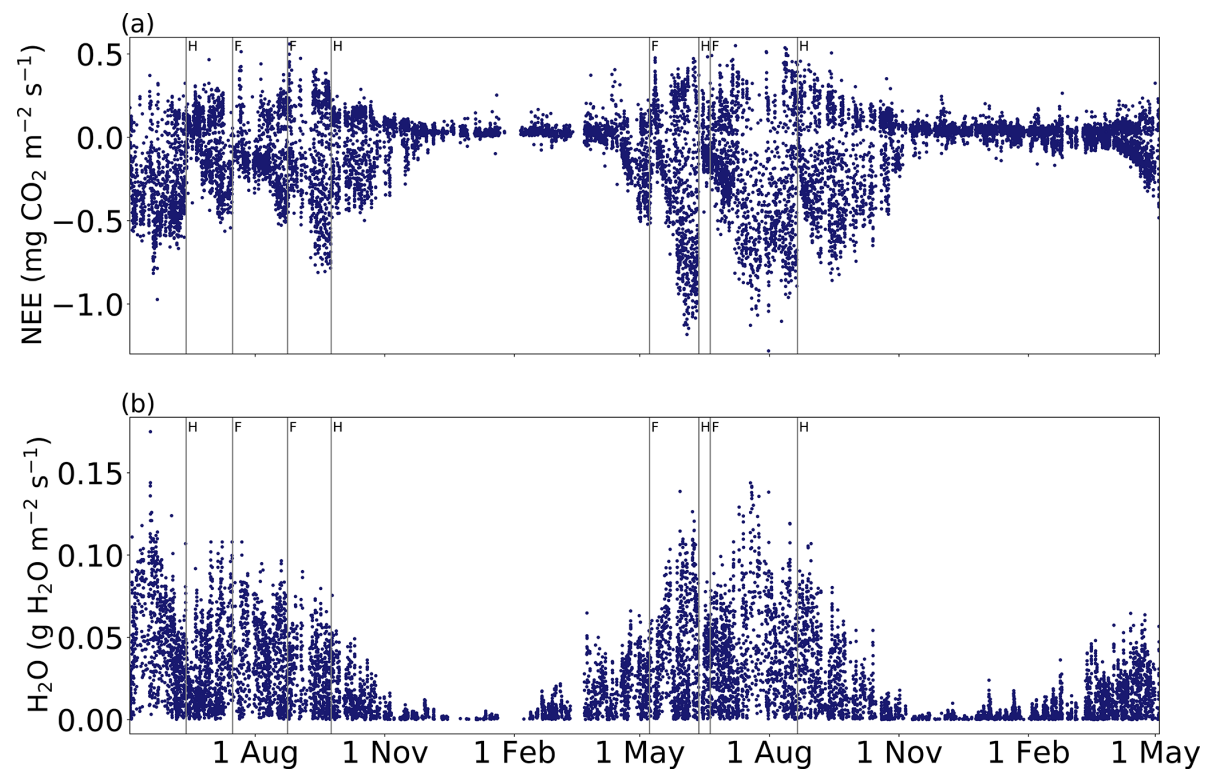

Figure 3. Accepted 30 min (a) net ecosystem exchange (NEE) and (b) $\mathrm{H}_{2} \mathrm{O}$ flux measurements from May 2018 to May 2020 . Vertical lines with $\mathrm{H}$ and $\mathrm{F}$ indicate harvest and fertilization, respectively.

Table 2. The annual carbon balances and their components $\left(\mathrm{g} \mathrm{C} \mathrm{m}^{-2} \mathrm{yr}^{-1}\right)$ for the 2 measurement years. Negative values indicate $\mathrm{C}$ input into the ecosystem, whereas positive values indicate $\mathrm{C}$ loss. Management (M) is the sum of the $\mathrm{C}$ fluxes due to harvest (positive) and fertilization (negative) events (Table 1). The values after \pm represent the uncertainty in NEE.

\begin{tabular}{lrrrrr}
\hline & NEE & GPP & $R_{\text {eco }}$ & M & Total balance \\
\hline First year & -62 & -1121 & 1053 & 5 & $-57 \pm 10$ \\
Second year & -216 & -1583 & 1362 & 130 & $-86 \pm 12$ \\
\hline
\end{tabular}

Table 3. Net ecosystem exchange of $\mathrm{CO}_{2}\left(\mathrm{NEE}, \mathrm{g} \mathrm{CO}_{2} \mathrm{~m}^{-2}\right)$, its components gross primary production (GPP) and ecosystem respiration $\left(R_{\mathrm{eco}}\right)$, and evapotranspiration $(\mathrm{ET}, \mathrm{mm})$ during the growing season (4 May to 30 September) in 2018 and 2019.

\begin{tabular}{rrrrr}
\hline Year & NEE & GPP & $R_{\text {eco }}$ & ET \\
\hline 2018 & -601 & -3330 & 2715 & 297 \\
2019 & -1176 & -4955 & 3771 & 283 \\
\hline
\end{tabular}

by $23 \%$ and management by $96 \%$. The components in the mean annual $\mathrm{CO}_{2}$ fluxes between the field and the atmosphere also indicated major differences between the growing seasons (Table 3). In 2019, the magnitude of the growing season NEE was $78 \%$, GPP $49 \%$ and $R_{\text {eco }} 42 \%$ higher than in 2018.

The average soil carbon storage in the $1 \mathrm{~m}$ layer was $16.59 \pm 2.25 \mathrm{~kg} \mathrm{~m}^{-2}$ (average \pm standard deviation), with the highest SOC found in the top $30 \mathrm{~cm}$ layer (Fig. 7). To estimate the increase in soil carbon storage, it was assumed that the magnitude of the net carbon balance represented the amount of carbon accumulated in the soil. Furthermore, to evaluate whether the field had the potential to fulfil the "4 per 1000" initiative, the annual net carbon balance was compared to the average soil carbon content. Thus, the estimated increase in soil carbon storage was $0.3 \%$ and $0.5 \%$ in the first and second years, respectively. On average, the annual carbon input to the soil accounted for $0.4 \%$ of the SOC.

\section{Discussion}

\subsection{Fluxes and carbon balance}

There is an urgent need to find evidence-based climatefriendly practices in agriculture in the boreal region, where the growing season is short and varieties differ from those cultivated in the temperate region. The carbon fluxes we measured on the agricultural grassland at the Qvidja farm in southern Finland clearly indicated that this site was a sink of atmospheric carbon. The annual NEE was $-62 \mathrm{~g} \mathrm{C} \mathrm{m}^{-2} \mathrm{yr}^{-1}$ in the first study year (4 May 2018-3 May 2019) and $-216 \mathrm{~g} \mathrm{C} \mathrm{m}^{-2} \mathrm{yr}^{-1}$ in the second year (4 May 2019-3 May 2020). The GPP showed notable variation between the study years as the annual GPP was -1121 and $-1583 \mathrm{~g} \mathrm{C} \mathrm{m}^{-2} \mathrm{yr}^{-1}$ in the first and second years, respectively. Gilmanov et al. (2010) reported a range of -2107 to $-1410 \mathrm{~g} \mathrm{C} \mathrm{m}^{-2} \mathrm{yr}^{-1}$ for the GPP of European managed grasslands. Our results fall below or in the lower end of this range. The annual $R_{\text {eco }}$ in Qvidja also varied between the study years (1053 and $\left.1362 \mathrm{~g} \mathrm{C} \mathrm{m}^{-2} \mathrm{yr}^{-1}\right)$. The annual $R_{\mathrm{eco}}$ in the European grasslands is reported to vary between 494 

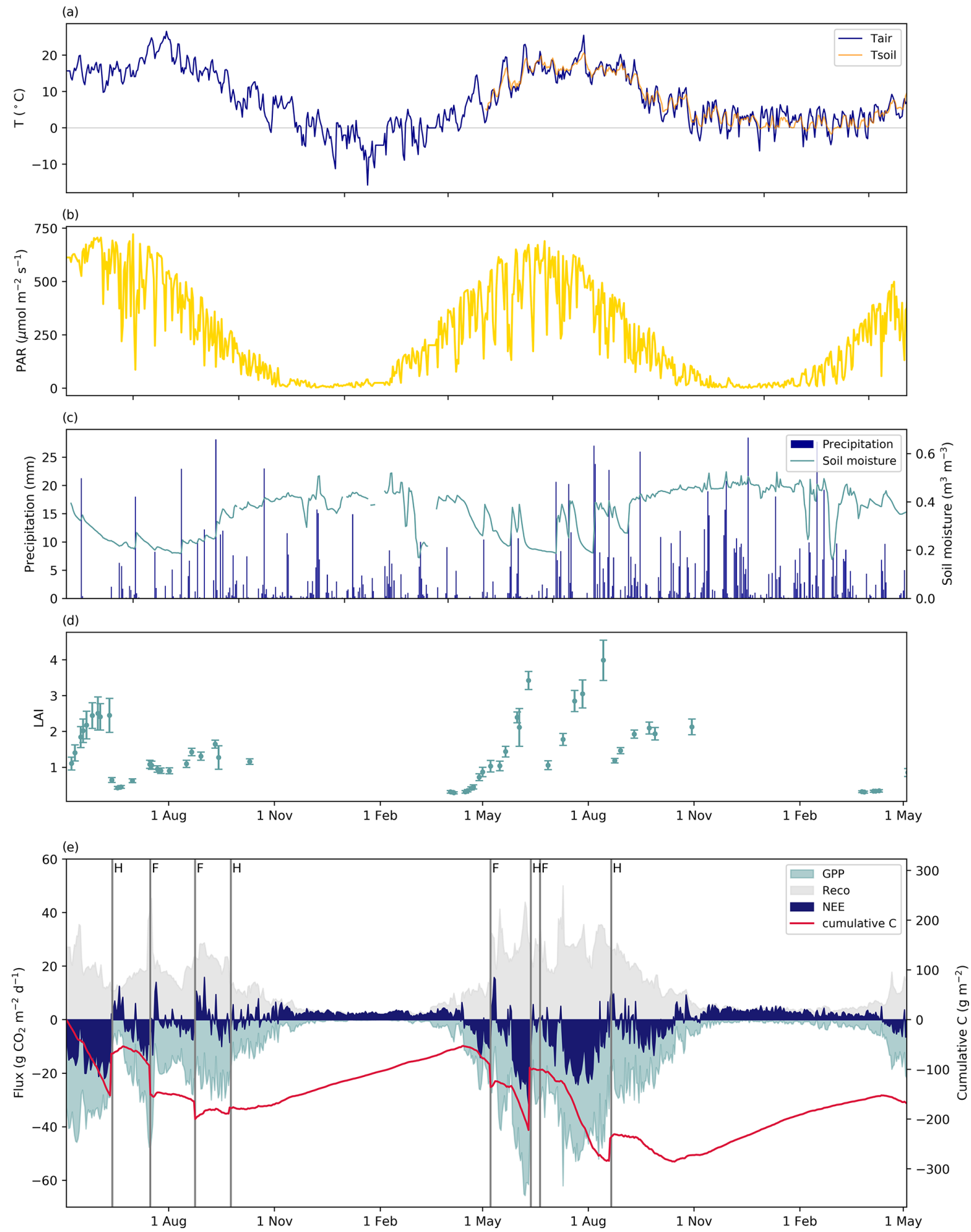

Figure 4. Daily mean (a) air and soil (depth $=0.05 \mathrm{~m}$ ) temperature, (b) photosynthetically active radiation (PAR), (c) precipitation and soil moisture $($ depth $=0.1 \mathrm{~m})$, (d) leaf area index $(\mathrm{LAI})$, and (e) daily mean NEE, GPP, $R_{\mathrm{eco}}$ and cumulative carbon flux from May 2018 to May 2020 . 

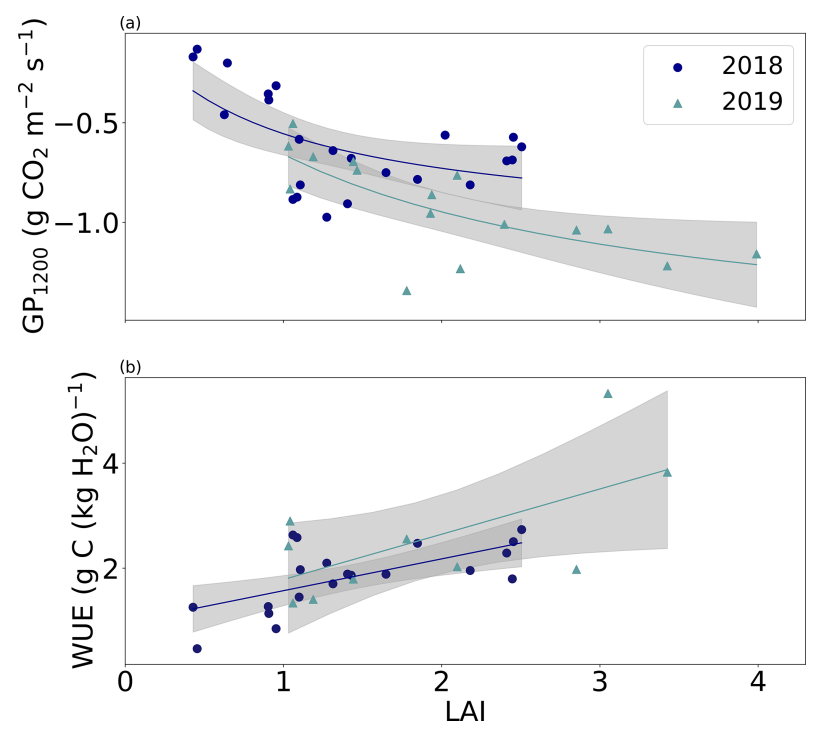

Figure 5. (a) Daily photosynthetic capacity $\left(\mathrm{GP}_{1200}\right)$ and (b) water use efficiency (WUE) as a function of leaf area index (LAI) during the two growing seasons. Grey areas represent the uncertainty bands.

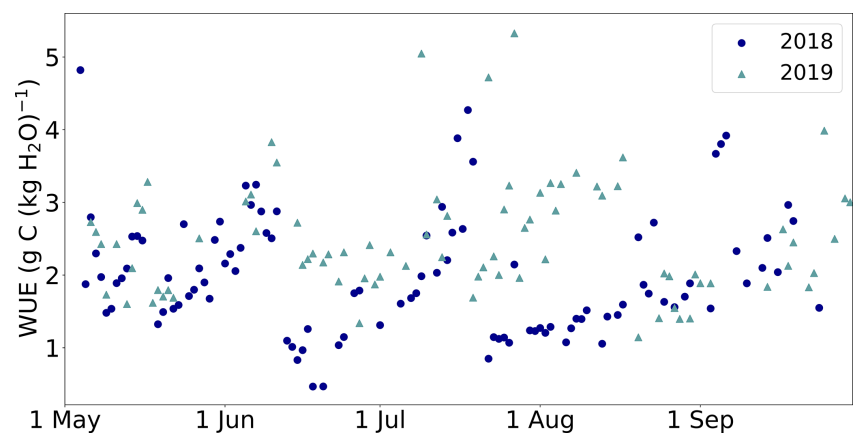

Figure 6. Daily water use efficiency (WUE) during two growing seasons.

and $1623 \mathrm{~g} \mathrm{C} \mathrm{m}^{-2} \mathrm{yr}^{-1}$ (Gilmanov et al., 2007). Our observations are thus also within this range.

To answer our first research question, we concluded that the carbon balance was negative in both study years $\left(-57 \pm 10\right.$ and $\left.-86 \pm 12 \mathrm{~g} \mathrm{C} \mathrm{m}^{-2} \mathrm{yr}^{-1}\right)$, and thus the field acted as a net carbon sink during the study period. In comparison, the Finnish agricultural fields measured so far were generally carbon sources when ecosystem-atmosphere $\mathrm{CO}_{2}$ fluxes, harvests and the carbon supplied to the system as fertilizers were considered (Heikkinen et al., 2013; Shurpali et al., 2009; Lind et al., 2016; Lohila et al., 2004). Lind et al. (2016) reported a slightly more negative annual NEE (2year average NEE $-259 \mathrm{~g} \mathrm{C} \mathrm{m}^{-2} \mathrm{yr}^{-1}$ ) for a grassland site on mineral soil than we observed in Qvidja. However, by considering the total carbon balance of the system by taking into account the carbon fluxes related to biomass removal as grass yield, it was concluded that their site acted as a net carbon source. Mineral fertilizers were used during their study, and thereby no carbon was imported to the field to compensate for the biomass removal from the system as harvests. Similar management-related carbon flux patterns were observed by Eichelmann et al. (2016), who reported a more negative NEE (average $-405 \mathrm{~g} \mathrm{C} \mathrm{m}^{-2} \mathrm{yr}^{-1}$ ) for an agricultural grassland in Canada than the NEE in Qvidja; however, the 2-year mean annual carbon balance was positive when biomass removal was taken into account, i.e. the Canadian field was a net source of carbon. It is noteworthy that the yield in Qvidja was substantially smaller than at the other two study sites (Lind et al., 2016; Eichelmann et al., 2016), at which the total balance became positive when the management activities, i.e. harvests and fertilization, were taken into account. The total carbon balance of the field depends greatly both on the amount of organic matter imported to the system as fertilizers and on the harvest yields, which are affected, for instance, by the applied cutting height.

Analysis of the weather variables in Qvidja indicated that temperature and moisture conditions were associated with the differences in $\mathrm{CO}_{2}$ flux dynamics and carbon balance between the study years. The growing season was warmer and drier in 2018 than 2019, with $13 \%$ lower mean soil moisture, $32 \%$ lower precipitation, $2.2{ }^{\circ} \mathrm{C}$ higher mean air temperature and $12 \%$ higher mean radiation during the growing season, and substantially smaller fluxes were observed in the first year. This is in accordance with Shurpali et al. (2009), who observed a positive correlation between the uptake of atmospheric $\mathrm{CO}_{2}$ (GPP) and both soil moisture and air temperature on another Finnish agricultural grassland. According to their conclusions, moderate temperature with high soil moisture enhanced $\mathrm{CO}_{2}$ uptake. Furthermore, Flanagan et al. (2002) and Kurc and Small (2007) concluded that rather wet summer conditions favoured photosynthetic activity in grasslands. These findings would support the conclusion that low soil moisture and high temperatures were the main factors limiting $\mathrm{CO}_{2}$ uptake at our study site in the summer 2018. However, this question remains partly open, as weather conditions, grass age and grass leaf area all showed different dynamics between the study years. In Finland, it is typical to grow grasslands for 3-4 years before grass renewal. In Qvidja, the grass was not renewed between the study years, which may have led to the larger fluxes observed in the second year when the grass root system, for instance, was likely to be more developed, enhancing water and nutrient availability and thus reducing the effect of drought stress. Furthermore, the leaf area was larger, and other capabilities, such as microbial symbioses (e.g. de Vries et al., 2020; Harman and Uphoff, 2019; Moreau et al., 2019), of the more developed grass may have increased carbon uptake. The lower leaf area during the first year was most probably also due to the dry summer, as shortage of water is a growth-limiting factor. Besides the leaf area, the photosynthetic potential per leaf area was lower in the first year, indicating either drought stress or shortage of nutrients, as temperature, a widely limiting factor 

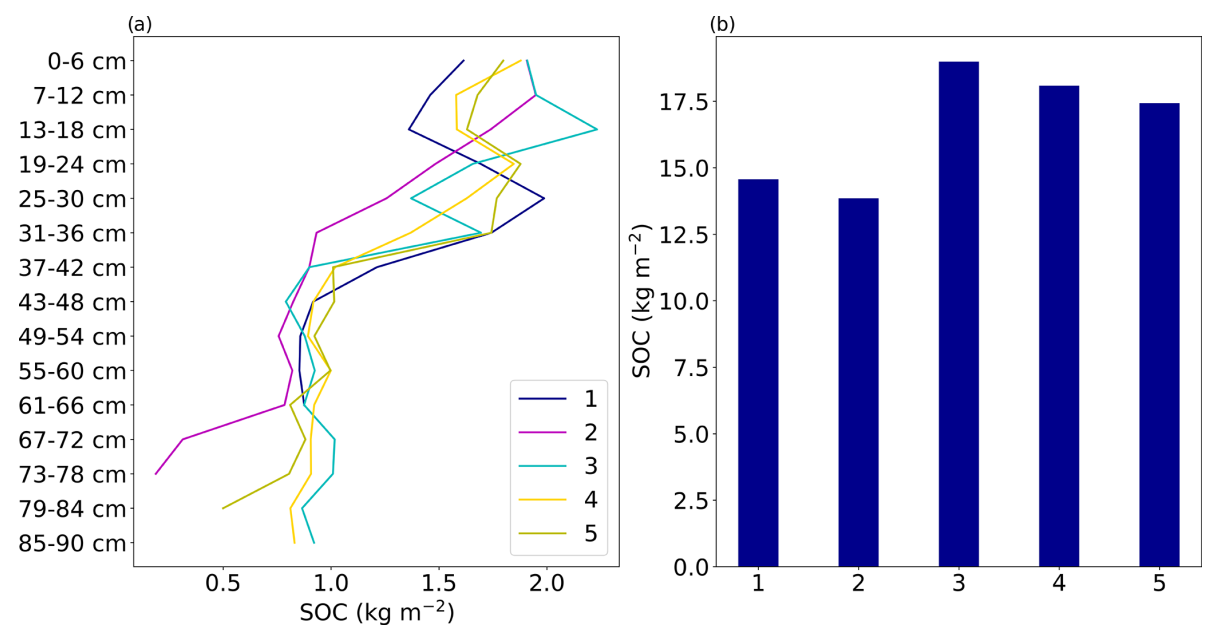

Figure 7. (a) Soil organic carbon (SOC) content at different depths in the $1 \mathrm{~m}$ deep soil samples, and (b) the total SOC in the samples. Numbers from 1 to 5 indicate sample numbers.

in northern latitudes, was high enough during both summers not to restrict photosynthesis. In any case, a more specific analysis of the driving and inhibiting environmental factors will require a longer measurement period.

Our second research question concerned the droughtrelated restrictions of photosynthesis. It has been widely recognized that in dry conditions plants are able to reduce transpiration by stomatal regulation (Willmer and Fricker, 1996). However, grasses seem to limit stomatal functions only in severe, prolonged drought conditions (Wolf et al., 2013; Xu et al., 2019), and thus occasional or seasonal drought events may not be observed in the ecosystem WUE of grasslands. In our study, WUE values were predominantly lower in 2018 than in 2019. This was most probably explained by the differences in LAI, as the relationship between WUE and LAI was similar during both growing seasons (Fig. 5b). Furthermore, the drier conditions with high temperatures in the summer 2018 may have resulted in a decoupling of assimilation and transpiration and in temperature-induced downregulation of GPP (Gharun et al., 2020), as ET was similar in both years (Table 3). Therefore, the clearly lower leaf-area-based photosynthetic capacity $\left(\mathrm{GP}_{1200}\right)$ in 2018 compared to 2019 probably indicates drought-related stress on photosynthetic processes despite the similar leaf-area-based WUE (Fig. 5). It is noteworthy that the WUE analysis was performed by means of the total ecosystem ET rather than plant transpiration, which would have enabled a more direct determination of the actual plant WUE and thus a simpler interpretation of plant processes and their relation to LAI. Nevertheless, days with even slight precipitation were eliminated from the analysis, and therefore we can assume that during the growing season most of the water flux arises from transpiration. In general, WUE at our study site varied mainly between 0 and $4 \mathrm{gC}\left(\mathrm{kg} \mathrm{H}_{2} \mathrm{O}\right)^{-1}$. This is consistent with the WUEs ob- served on northern grasslands $\left(0-7 \mathrm{~g} \mathrm{C}\left(\mathrm{kg} \mathrm{H}_{2} \mathrm{O}\right)^{-1}\right)$ (Tang et al., 2014).

The different management practices, such as fertilization and the choice of grass cutting height, were slightly different in the first and second years, which probably had an impact on the carbon balances. In June 2018, a conventional cutting height of $6 \mathrm{~cm}$ was used, whereas in the other harvests the grass was cut at $15 \mathrm{~cm}$. The higher cutting height may have enhanced the regrowth of grass, especially in the more favourable weather conditions in 2019, and with a larger leaf area higher $\mathrm{CO}_{2}$ uptake was observed right after the harvest. Only after the $6 \mathrm{~cm}$ harvest did the field turn to a net source of $\mathrm{CO}_{2}$. With a low cutting height, it was more likely that the grass was cut below the growing point, particularly in dry conditions, which affects the stand longevity and stress tolerance (Jones and Tracy, 2018). As the weather was warm and dry during the harvest events in June in both years, a higher cutting height may have served as a vital management improvement.

The field was mainly fertilized with organic substances, and thus carbon was imported to the system, affecting the net carbon balance. After each of the fertilization events with organic material, the respiration of the field increased, whereas mineral fertilization was not observed to have an immediate effect on $\mathrm{CO}_{2}$ fluxes. Increased respiration was likely to occur due to microbial activity of the organic fertilizers. Gilmanov et al. (2007) observed on a Danish agricultural grassland that, although the application of manure increased respiration, the plant uptake of $\mathrm{CO}_{2}$ was notably higher than at the other sites studied. Fornara et al. (2016) also concluded, based on their 43-year study, that manure fertilization substantially increased soil carbon sequestration of a grassland ecosystem in Northern Ireland. Although the type of the organic fertilizer possibly plays a crucial role, the application of carbon to the system has a direct effect on the carbon 
balance, but there is also an indirect effect on its components $R_{\text {eco }}$ and GPP via soil and plant functions.

Concerning our final research question on the relation of the carbon balance to the international " 4 per 1000" carbon sequestration initiative (Minasny et al., 2017), our results show that the Qvidja field acted as an annual net carbon sink and had the potential to fulfil the goal of this initiative and to contribute to the short-term climate change mitigation. By considering the carbon balance by accounting for the ecosystem-atmosphere $\mathrm{CO}_{2}$ fluxes and the carbon fluxes caused by management activities and comparing that to the measured soil carbon content, the carbon storage of the field increased on average by $0.4 \%$ annually over the studied period. To draw a more reliable conclusion about the carbon sequestration, leaching and other carbon-containing compounds must also be considered in further studies about the carbon balance. Furthermore, the number of soil carbon samples should be increased for a more accurate evaluation of the soil carbon storage of the field, even though the variation among the present samples was small. However, the estimated annual carbon balance of our second study year $\left(-86 \mathrm{~g} \mathrm{C} \mathrm{m}^{-2} \mathrm{yr}^{-1}\right)$ with improved management practices was within the range of annual carbon sequestration potential $\left(80-120 \mathrm{~g} \mathrm{C} \mathrm{m}^{-2} \mathrm{yr}^{-1}\right)$ that is evaluated to be attainable with improved management practices (Lal, 2016). Thus, this study demonstrates the potential for a positive impact of northern agricultural grasslands in terms of climate change mitigation.

\subsection{Errors and uncertainties}

Uncertainties in the results are mainly related to the gaps in the measurement data, which required gap-filling of missing measurements with modelled data. The length of a gap increases the related uncertainty, but in our data there were only three longer gaps (4, 8 and $9 \mathrm{~d})$, which all occurred during the first winter, when temperatures were low and only minor fluxes could have been observed. All the other gaps were shorter than $3 \mathrm{~d}$. However, each gap contributed to the uncertainty and were included in the carbon balance calculations. Further uncertainties, which were not included in the error estimates, were involved in the yield measurements and fertilization input estimates, as well as in the fairly scarce sample size of the soil carbon content measurements.

Carbon balance was calculated based on the ecosystematmosphere $\mathrm{CO}_{2}$ fluxes and the inputs and outputs of harvest and fertilization. Thus, no other gaseous carbon compounds, such as methane, were considered. Regina et al. (2007) reported that the annual methane balances of a Finnish clay soil for 2 years were -0.009 and $0.034 \mathrm{~g} \mathrm{CH}_{4} \mathrm{~m}^{-2} \mathrm{yr}^{-1}$. Based on this estimate, the possible carbon emission as methane accounts for less than $1 \%$ of our annual carbon balance.

Leaching of dissolved carbon and emissions of volatile organic compounds may have had an effect on the annual carbon balance. Leaching of carbon from the agricultural soils is mainly driven by meteorological and hydrological conditions (Manninen et al., 2018), but it is also affected by soil properties (Don and Schulze, 2008). Large variations in soil moisture and temperature and precipitation may increase the solubility of SOM. Generally, however, clay soils retain carbon better than other soil types. Furthermore, ploughing increases leaching as mineralization of SOM is enhanced. Depending on precipitation and hydrological and chemical properties of the soil, carbon leaching on grasslands may equal approximately $25 \%$ of the annual carbon balance calculated based on NEE, harvest and fertilization (Kindler et al., 2011). At our study site, the effect of leaching on the annual carbon balance could be assumed to be fairly small in both summers due to low soil moisture and low precipitation. In winter, the leaching may have caused a temporary contribution to the carbon balance during wet periods and thus reduced the increase in soil carbon storage. For a more accurate carbon balance estimate of this site, however, the contribution of leaching and all carbon-containing gases (e.g. $\mathrm{CH}_{4}$ ) should be measured and the number of soil carbon storage measurements increased.

\section{Conclusions}

The agricultural grassland site located at Qvidja in southern Finland acted as a net carbon sink during the 2 years studied. The carbon balance of the first study year was $-57 \pm 10 \mathrm{~g} \mathrm{C} \mathrm{m}^{-2} \mathrm{yr}^{-1}$, and in the second year it was $-86 \pm 12 \mathrm{~g} \mathrm{C} \mathrm{m}^{-2} \mathrm{yr}^{-1}$. When $\mathrm{CO}_{2}$ fluxes and carbon fluxes caused by management activities were solely accounted for, the soil carbon storage was assumed to have increased by $0.3 \%$ and $0.5 \%$ in 2018 and 2019, respectively, indicating that northern agricultural grasslands have a potential to contribute to climate change mitigation. The data and results presented here act as a basis for the future studies that focus on the conversion of this farm from intensive agricultural practices towards more sustainable agricultural management, especially on the impacts of such a conversion on the GHG fluxes occurring on mineral soils in northern conditions. Even though we could quantify the sink capacity of the field, further research with longer-term measurements is needed to evaluate the persistence of carbon sequestration and storage, and wider measurements of carbon balance components were to be included. Longer time series and broader GHG flux measurements are also essential to more closely study the causes of the interannual variation in GHG fluxes and carbon and water balances at this site, for which the present study provides a baseline. 


\section{Appendix A: Gap-filling of $\mathrm{CO}_{2}$ fluxes}

The flux data set was separated into sections at the harvest dates, and gap-filling was done separately for these sections by first parameterizing and calculating $R_{\text {eco }}$ and then GPP. The parameter $R_{0}$ was determined for each day from the nighttime data (PAR $<20 \mu \mathrm{mol} \mathrm{m}^{-2} \mathrm{~s}^{-1}$ ) with a $7 \mathrm{~d}$ moving window. $E_{0}$ was determined within the same moving window as $R_{0}$. If there were fewer than 24 measurements within the time window, its length was increased by $1 \mathrm{~d}$ at both the beginning and end until enough data were obtained. $R_{0}$ was allowed to vary between 0.001 and $1 \mathrm{mg} \mathrm{m}^{-2} \mathrm{~s}^{-1}$. The same minimum number of observations within a $3 \mathrm{~d}$ moving window was used for determining $\alpha$ and $\mathrm{GP}_{\max }$ from the observed NEE from which the estimated $R_{\text {eco }}$ had been subtracted. $\alpha$ and $\mathrm{GP}_{\max }$ were allowed to vary between -0.5 and

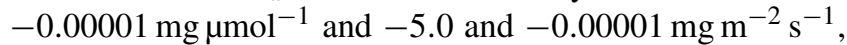
respectively.

\section{Appendix B: Gap-filling of energy fluxes}

The gaps in the net radiation $\left(R_{\mathrm{n}}\right)$ time series were filled with the monthly mean diurnal cycles. Soil heat flux $(G)$ was not measured at our site, so it was estimated from the energy balance closure during the periods when the other energy fluxes were known. Gap-filling of $G$ was done by assuming a constant ratio between $G$ and $R_{\mathrm{n}}$ (Liebethal and Foken, 2007). The ratio of 0.24 was calculated with linear regression from the daytime data (between 10:00-15:00 local time, UTC+2). The sensible and latent heat fluxes $\left(Q_{H}\right.$ and $Q_{E}$, respectively) were gap-filled based on the procedure described by Kowalski et al. (2003). The gaps in the daytime $Q_{H}\left(R_{\mathrm{n}}>0\right)$ were filled with monthly linear regression with $R_{\mathrm{n}}$. The nighttime gaps in $Q_{H}\left(R_{\mathrm{n}}<0\right)$ were filled with the corresponding $R_{\mathrm{n}}$ values. The gaps in the daytime $Q_{E}$ were filled in such a way that the monthly mean energy balance closure was achieved. The nighttime gaps in $Q_{E}$ were set to 0 .

\section{Appendix C: Management effect on fluxes}

The immediate effect of management on the measured NEE and WUE was investigated by comparing the mean values of $5 \mathrm{~d}$ before and after the management day (Table C1).

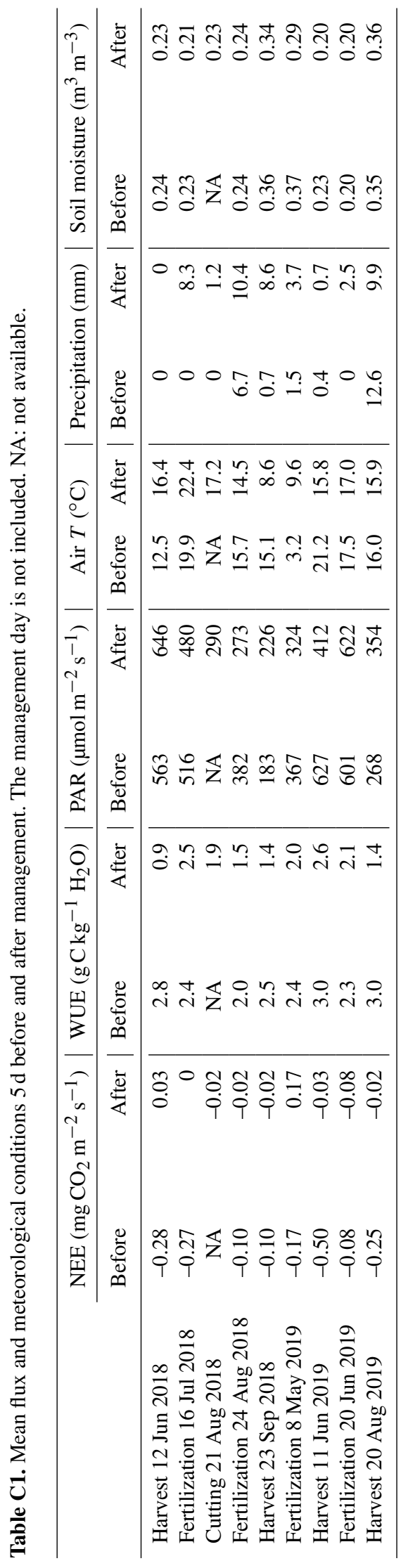

Biogeosciences, 18, 3467-3483, 2021 
Data availability. The flux and meteorological data as well as the SOC measurements and LAI data are available at Zenodo (https://doi.org/10.5281/zenodo.4647078, Heimsch et al., 2020).

Author contributions. JL and TL planned the flux measurements and TL was responsible for the setup. JPT made the post-processing data corrections and calculated the flux footprint. HV and MK developed the gap-filling code. $\mathrm{LH}$ filtered the data and carried out the data analysis. JH provided the soil carbon data and ON processed the Sentinel-2 LAI data. LH, AL, JPT and LK prepared the manuscript with contributions from all co-authors.

Competing interests. The authors declare that they have no conflict of interest.

Acknowledgements. This study was supported by SITRA, Business Finland (grant 6905/31/2018) and The Strategic Research Council at the Academy of Finland (grant no 327214). We acknowledge MSc student Niina Ruoho for skilful technical assistance. Qvidja farm owners and staff, especially Pekka Heikkinen and Jonathan Nylund are greatly acknowledged for diverse practical assistance and management of the field.

Financial support. This research has been supported by the Business Finland (grant no. 6905/31/2018) and the Academy of Finland (grant no. 327214).

Review statement. This paper was edited by Lutz Merbold and reviewed by two anonymous referees.

\section{References}

Abraha, M., Gelfand, I., Hamilton, S. K., Shao, C., Su, Y.-J., Robertson, G. P., and Chen, J.: Ecosystem water-use efficiency of annual corn and perennial grasslands: contributions from land-use history and species composition, Ecosystems, 19, 1001-1012, https://doi.org/10.1007/s10021-016-9981-2, 2016.

Aubinet, M., Vesala, T., and Papale, D.: Eddy Covariance: A Practical Guide to Measurement and Data Analysis, Springer, Dordrecht, The Netherlands, 438 pp., https://doi.org/10.1007/97894-007-2351-1, 2012.

Aurela, M., Laurila, T., and Tuovinen, J.-P.: Annual $\mathrm{CO}_{2}$ balance of a subarctic fen in northern Europe: importance of the wintertime efflux, J. Geophys. Res.-Atmos., 107, 4607, https://doi.org/10.1029/2002JD002055, 2002.

Baldocchi, D., Chu, H., and Reichstein, M.: Interannual variability of net and gross ecosystem carbon fluxes: A review, Agr. Forest Meteorol., 249, 520-533, https://doi.org/10.1016/j.agrformet.2017.05.015, 2018.

Baldocchi, D. D.: Assessing the eddy covariance technique for evaluating carbon dioxide exchange rates of ecosystems: past, present and future, Global Change Biol., 9, 479-492, https://doi.org/10.1046/j.1365-2486.2003.00629.x, 2003.

Bastos, A., Ciais, P., Friedlingstein, P., Sitch, S., Pongratz, J., Fan, L., Wigneron, J., Weber, U., Reichstein, M., Fu, Z., Anthoni, P., Arneth, A., Haverd, V., Jain, A. K., Joetzjer, E., Knauer, J., Lienert, S., Loughran, T., McGuire, P. C., Tian, H., Viovy, N., and Zaehle, S.: Direct and seasonal legacy effects of the 2018 heat wave and drought on European ecosystem productivity, Science Advances, 6, eaba2724, https://doi.org/10.1126/sciadv.aba2724, 2020.

Bolinder, M., Kätterer, T., Andrén, O., Ericson, L., Parent, L.E., and Kirchmann, H.: Long-term soil organic carbon and nitrogen dynamics in forage-based crop rotations in Northern Sweden (63-64 N), Agr. Ecosyst. Environ., 138, 335-342, https://doi.org/10.1016/j.agee.2010.06.009, 2010.

Brunsell, N., Nippert, J., and Buck, T.: Impacts of seasonality and surface heterogeneity on water-use efficiency in mesic grasslands, Ecohydrology, 7, 1223-1233, https://doi.org/10.1002/eco.1455, 2014.

Ceschia, E., Béziat, P., Dejoux, J.-F., Aubinet, M., Bernhofer, C., Bodson, B., Buchmann, N., Carrara, A., Cellier, P., Di Tommasi, P., Elbers, J. A., Eugster, W., Grünwald, T., Jacobs, C. M. J., Jans, W. W. P., Jones, M., Kutsch, W., Lanigan, G., Magliulo, E., Marloie, O., Moors, E. J., Moureaux, C., Olioso, A., Osborne, B., Sanz, M. J., Saunders, M., Smith, P., Soegaard, H., and Wattenbach, M.: Management effects on net ecosystem carbon and GHG budgets at European crop sites, Agr. Ecosyst. Environ., 139, 363-383, https://doi.org/10.1016/j.agee.2010.09.020, 2010.

Chapin, F. S., Woodwell, G. M., Randerson, J. T., Rastetter, E. B., Lovett, G. M., Baldocchi, D. D., Clark, D. A., Harmon, M. E., Schimel, D. S., Valentini, R., Wirth, C., Aber, J. D., Cole, J. J., Goulden, M. L., Harden, J. W., Heimann, M., Howarth, R. W., Matson, P. A., McGuire, A. D., Melillo, J. M., Mooney, H. A., Neff, J. C., Houghton, R. A., Pace, M. L., Ryan, M. G., Running, S. W., Sala, O. E., Schlesinger, W. H., and Schulze, E.-D.: Reconciling carbon-cycle concepts, terminology, and methods, Ecosystems, 9, 1041-1050, 2006.

Ciais, P., Reichstein, M., Viovy, N., Granier, A., Ogée, J., Allard, V., Aubinet, M., Buchmann, N., Bernhofer, C., Carrara, A., Chevallier, F., De Noblet, N., Friend, A. D., Friedlingstein, P., Grünwald, T., Heinesch, B., Keronen, P., Knohl, A., Krinner, G., Loustau, D., Manca, G., Matteucci, G., Miglietta, F., Ourcival, J. M., Papale, D., Pilegaard, K., Rambal, S., Seufert, G., Soussana, J. F., Sanz, M. J., Schulze, E. D., Vesala, T., and Valentini, R.: Europe-wide reduction in primary productivity caused by the heat and drought in 2003, Nature, 437, 529-533, https://doi.org/10.1038/nature03972, 2005.

Ciais, P., Sabine, C., Bala, G., Bopp, L., Brovkin, V., Canadell, J., Chhabra, A., DeFries, R., Galloway, J., Heimann, M., Jones, C., Le Quéré, C., Myneni, R. B., Piao S., and Thorn, P.: Carbon and other biogeochemical cycles, in: Climate change 2013: the physical science basis, Contribution of Working Group I to the Fifth Assessment Report of the Intergovernmental Panel on Climate Change, Cambridge University Press, Cambridge, UK, available at: https://pure.mpg.de/rest/items/item_2058766/ component/file_2058769/content (last access: 8 February 2021), 465-570, 2014.

De Boeck, H. J., Lemmens, C. M., Bossuyt, H., Malchair, S., Carnol, M., Merckx, R., Nijs, I., and Ceulemans, R.: How 
do climate warming and plant species richness affect water use in experimental grasslands?, Plant Soil, 288, 249-261, https://doi.org/10.1007/s11104-006-9112-5, 2006.

de Vries, F. T., Griffiths, R. I., Knight, C. G., Nicolitch, O., and Williams, A.: Harnessing rhizosphere microbiomes for drought-resilient crop production, Science, 368, 270-274, https://doi.org/10.1126/science.aaz5192, 2020.

Don, A. and Schulze, E.-D.: Controls on fluxes and export of dissolved organic carbon in grasslands with contrasting soil types, Biogeochemistry, 91, 117-131, https://doi.org/10.1007/s10533008-9263-y, 2008.

Donnelly, C., Greuell, W., Andersson, J., Gerten, D., Pisacane, G., Roudier, P., and Ludwig, F.: Impacts of climate change on European hydrology at 1.5, 2 and 3 degrees mean global warming above preindustrial level, Climatic Change, 143, 13-26, https://doi.org/10.1007/s10584-017-1971-7, 2017.

Eichelmann, E., Wagner-Riddle, C., Warland, J., Deen, B., and Voroney, P.: Carbon dioxide exchange dynamics over a mature switchgrass stand, GCB Bioenergy, 8, 428-442, https://doi.org/10.1111/gcbb.12259, 2016.

Flanagan, L. B., Wever, L. A., and Carlson, P. J.: Seasonal and interannual variation in carbon dioxide exchange and carbon balance in a northern temperate grassland, Global Change Biol., 8, 599615, https://doi.org/10.1046/j.1365-2486.2002.00491.x, 2002.

Foken, T., Leuning, R., Oncley, S. R., Mauder, M., and Aubinet, M.: Corrections and data quality control, in: Eddy covariance, Springer, Dordrecht, 85-131, https://doi.org/10.1007/97894-007-2351-1_4, 2012.

Fornara, D. A., Wasson, E.-A., Christie, P., and Watson, C. J.: Long-term nutrient fertilization and the carbon balance of permanent grassland: any evidence for sustainable intensification?, Biogeosciences, 13, 4975-4984, https://doi.org/10.5194/bg-134975-2016, 2016.

Fricker, M. and Willmer, C.: Stomata, Springer, Dordrecht, The Netherlands, https://doi.org/10.1007/978-94-011-0579-8, 2012.

Gharun, M., Hörtnagl, L., Paul-Limoges, E., Ghiasi, S., Feigenwinter, I., Burri, S., Marquardt, K., Etzold, S., Zweifel, R., Eugster, W., and Buchmann, N.: Physiological response of Swiss ecosystems to 2018 drought across plant types and elevation, Philos. T. Roy. Soc. B, 375, 20190521, https://doi.org/10.1098/rstb.2019.0521, 2020.

Gilmanov, T., Soussana, J.-F., Aires, L., Allard, V., Ammann, C., Balzarolo, M., Barcza, Z., Bernhofer, C., Campbell, C., Cernusca, A., Cescatti, A., Clifton-Brown, J., Dirks, B. O. M., Dore, S., Eugster, W., Fuhrer, J., Gimeno, C., Gruenwald, T., Haszpra, L., Hensen, A., Ibrom, A., Jacobs, A. F. G., Jones, M. B., Lanigan, G., Laurila, T., Lohila, A., Manca, G., Marcolla, B. Nagy, Z., Pilegaard, K., Pinter, K., Pio, C., Raschi, A., Rogiers, N., Sanz, M.J., Stefani, P., Sutton, M., Tuba, Z., Valentini, R., Williams, M. L., and Wohlfahrt, G.: Partitioning European grassland net ecosystem $\mathrm{CO}_{2}$ exchange into gross primary productivity and ecosystem respiration using light response function analysis, Agr. Ecosyst. Environ., 121, 93-120, https://doi.org/10.1016/j.agee.2006.12.008, 2007.

Gilmanov, T. G., Aires, L., Barcza, Z., Baron, V. S., Belelli, L., Beringer, J., Billesbach, D., Bonal, D., Bradford, J., Ceschia, E., Cook, D., Corradi, C., Frank, A., Gianelle, D., Gimeno, C., Gruenwald, T., Guo, H., Hanan, N., Haszpra, L., Heilman, J., Jacobs, A., Jones, M. B., Johnson, D. A., Kiely, G., Li, S., Magliulo,
V., Moors, E., Nagy, Z., Nasyrov, M., Owensby, C., Pinter, K., Pio, C., Reichstein, M., Sanz, M. J., Scott, R., Soussana, J. F., Stoy, P. C., Svejcar, T., Tuba, Z., and Zhou, G.: Productivity, respiration, and light-response parameters of world grassland and agroecosystems derived from flux-tower measurements, Rangeland Ecol. Manag., 63, 16-39, https://doi.org/10.2111/REM-D09-00072.1, 2010.

Gomez-Casanovas, N., Matamala, R., Cook, D. R., and GonzalezMeler, M. A.: Net ecosystem exchange modifies the relationship between the autotrophic and heterotrophic components of soil respiration with abiotic factors in prairie grasslands, Global Change Biol., 18, 2532-2545, https://doi.org/10.1111/j.13652486.2012.02721.x, 2012.

Harman, G. E. and Uphoff, N.: Symbiotic Root-Endophytic Soil Microbes Improve Crop Productivity and Provide Environmental Benefits, Scientifica, 2019, 9106395, https://doi.org/10.1155/2019/9106395, 2019.

Harrison, P. A., Dunford, R. W., Holman, I. P., Cojocaru, G., Madsen, M. S., Chen, P.-Y., Pedde, S., and Sandars, D.: Differences between low-end and high-end climate change impacts in Europe across multiple sectors, Reg. Environ. Change, 19, 695-709, https://doi.org/10.1007/s10113-018-1352-4, 2019.

Heikkinen, J., Ketoja, E., Nuutinen, V., and Regina, K.: Declining trend of carbon in Finnish cropland soils in 1974-2009, Global Change Biol., 19, 1456-1469, https://doi.org/10.1111/gcb.12137, 2013.

Heimsch, L., Lohila, A., Tuovinen, J.-P., Vekuri, H., Heinonsalo, J., Nevalainen, O., Korkiakoski, M., Liski, J., Laurila, T., and Kulmala, L.: Carbon dioxide fluxes and carbon balance of an agricultural grassland in southern Finland, Zenodo [Data set], https://doi.org/10.5281/zenodo.4647078, 2020.

Houghton, R. A. and Nassikas, A. A.: Global and regional fluxes of carbon from land use and land cover change 1850-2015, Global Biogeochem. Cy., 31, 456-472, https://doi.org/10.1002/2016GB005546, 2017.

Hu, Z., Yu, G., Fu, Y., Sun, X., Li, Y., Shi, P., Wang, Y., and Zheng, Z.: Effects of vegetation control on ecosystem water use efficiency within and among four grassland ecosystems in China, Global Change Biol., 14, 1609-1619, https://doi.org/10.1111/j.1365-2486.2008.01582.x, 2008.

Jensen, R., Herbst, M., and Friborg, T.: Direct and indirect controls of the interannual variability in atmospheric $\mathrm{CO}_{2}$ exchange of three contrasting ecosystems in Denmark, Agr. Forest Meteorol., 233, 12-31, https://doi.org/10.1016/j.agrformet.2016.10.023, 2017.

Johannes, A., Matter, A., Schulin, R., Weisskopf, P., Baveye, P. C., and Boivin, P.: Optimal organic carbon values for soil structure quality of arable soils: Does clay content matter?, Geoderma, 302, 14-21, 2017.

Jones, G. and Tracy, B.: Persistence and productivity of orchardgrass and orchardgrass/alfalfa mixtures as affected by cutting height, Grass Forage Sci., 73, 544-552, https://doi.org/10.1111/gfs.12309, 2018.

Kindler, R., Siemens, J., Kaiser, K., Walmsley, D. C., Bernhofer, C., Buchmann, N., Cellier, P., Eugster, W., Gleixner, G., Grũnwald, T., Heim, A., Ibrom, A., Jones, S. K., Jones, M., Klumpp, K., Kutsch, W., Larsen, K. S., Lehuger, S., Loubet, B., McKenzie, R., Moors, E., Osborne, B., Pilegaard, K., Rebmann, C., Saunders, M., Schmidt, M. W. I., Schrumpf, M., Seyfferth, 
J., Skiba, U., Soussana, J.-F., Sutton, M. A., Tefs, C., Vowinckel, B., Zeeman, M. J., and Kaupenjohann, M.: Dissolved carbon leaching from soil is a crucial component of the net ecosystem carbon balance, Global Change Biol., 17, 1167-1185, https://doi.org/10.1111/j.1365-2486.2010.02282.x, 2011.

Kormann, R. and Meixner, F. X.: An analytical footprint model for non-neutral stratification, Bound.-Lay. Meteorol., 99, 207-224, https://doi.org/10.1023/A:1018991015119, 2001.

Kowalski, S., Sartore, M., Burlett, R., Berbigier, P., and Loustau, D.: The annual carbon budget of a French pine forest (Pinus pinaster) following harvest, Global Change Biol., 9, 1051-1065, https://doi.org/10.1046/j.1365-2486.2003.00627.x, 2003.

Kurc, S. A. and Small, E. E.: Soil moisture variations and ecosystem-scale fluxes of water and carbon in semiarid grassland and shrubland, Water Resour. Res., 43, W06416, https://doi.org/10.1029/2006WR005011, 2007.

Kutsch, W., Aubinet, M., Buchmann, N., Smith, P., Osborne, B., Eugster, W., Wattenbach, M., Schrumpf, M., Schulze, E., Tomelleri, E., Ceschia, E., Bernhofer, C., Béziat, P., Carrara, A., Di Tommasi, P., Grünwald, T., Jones, M., Magliulo, V., Marloie, O., Moureaux, C., Olioso, A., Sanz, M. J., Saunders, M., Søgaard, H., and Ziegler, W.: The net biome production of full crop rotations in Europe, Agr. Ecosyst. Environ., 139, 336-345, 2010.

Lal, R.: Beyond COP 21: potential and challenges of the "4 per Thousand" initiative, J. Soil Water Conserv., 71, 20-25, https://doi.org/10.2489/jswc.71.1.20A, 2016.

Laurila, T., Tuovinen, J.-P., Lohila, A., Hatakka, J., Aurela, M., Thum, T., Pihlatie, M., Rinne, J., and Vesala, T.: Measuring methane emissions from a landfill using a cost-effective micrometeorological method, Geophys. Res. Lett., 32, L19808, https://doi.org/10.1029/2005GL023462, 2005.

Le Quéré, C., Raupach, M. R., Canadell, J. G., Marland, G., Bopp, L., Ciais, P., Conway, T. J., Doney, S. C., Feely, R. A., Foster, P., Friedlingstein, P., Gurney, K., Houghton, R. A., House, J. I., Huntingford, C., Levy, P. E., Lomas, M. R., Majkut, J., Metzl, N., Ometto, J. P., Peters, G. P., Prentice, I. C., Randerson, J. T., Running, S. W., Sarmiento, J. L., Schuster, U., Sitch, S., Takahashi, T., Viovy, N., van der Werf, G. R., and Woodward, F. I.: Trends in the sources and sinks of carbon dioxide, Nat. Geosci., 2, 831-836, https://doi.org/10.1038/ngeo689, 2009.

Le Quéré, C., Andrew, R. M., Friedlingstein, P., Sitch, S., Pongratz, J., Manning, A. C., Korsbakken, J. I., Peters, G. P., Canadell, J. G., Jackson, R. B., Boden, T. A., Tans, P. P., Andrews, O. D., Arora, V. K., Bakker, D. C. E., Barbero, L., Becker, M., Betts, R. A., Bopp, L., Chevallier, F., Chini, L. P., Ciais, P., Cosca, C. E., Cross, J., Currie, K., Gasser, T., Harris, I., Hauck, J., Haverd, V., Houghton, R. A., Hunt, C. W., Hurtt, G., Ilyina, T., Jain, A. K., Kato, E., Kautz, M., Keeling, R. F., Klein Goldewijk, K., Körtzinger, A., Landschützer, P., Lefèvre, N., Lenton, A., Lienert, S., Lima, I., Lombardozzi, D., Metzl, N., Millero, F., Monteiro, P. M. S., Munro, D. R., Nabel, J. E. M. S., Nakaoka, S., Nojiri, Y., Padin, X. A., Peregon, A., Pfeil, B., Pierrot, D., Poulter, B., Rehder, G., Reimer, J., Rödenbeck, C., Schwinger, J., Séférian, R., Skjelvan, I., Stocker, B. D., Tian, H., Tilbrook, B., Tubiello, F. N., van der Laan-Luijkx, I. T., van der Werf, G. R., van Heuven, S., Viovy, N., Vuichard, N., Walker, A. P., Watson, A. J., Wiltshire, A. J., Zaehle, S., and Zhu, D.: Global Carbon Budget 2017, Earth Syst. Sci. Data, 10, 405-448, https://doi.org/10.5194/essd-10-405-2018, 2018.
Liebethal, C. and Foken, T.: Evaluation of six parameterization approaches for the ground heat flux, Theor. Appl. Climatol., 88, 43-56, https://doi.org/10.1007/s00704-005-0234-0, 2007.

Lind, S. E., Shurpali, N. J., Peltola, O., Mammarella, I., Hyvönen, N., Maljanen, M., Räty, M., Virkajärvi, P., and Martikainen, P. J.: Carbon dioxide exchange of a perennial bioenergy crop cultivation on a mineral soil, Biogeosciences, 13, 1255-1268, https://doi.org/10.5194/bg-13-1255-2016, 2016.

Lind, S. E., Virkajärvi, P., Hyvönen, N. P., Maljanen, M., Kivimäenpää, M., Jokinen, S., Antikainen, S., Latva, M., Räty, M., and Martikainen, P. J.: Carbon dioxide and methane exchange of a perennial grassland on a boreal mineral soil, Boreal Environ. Res., 25, 1-17, http://urn.fi/URN:NBN:fi-fe202002135420 (last access: 15 February 2021), 2020.

Lloyd, J. and Taylor, J.: On the temperature dependence of soil respiration, Funct. Ecol., 8, 315-323, https://doi.org/10.2307/2389824, 1994.

Lohila, A., Aurela, M., Tuovinen, J.-P., and Laurila, T.: Annual $\mathrm{CO}_{2}$ exchange of a peat field growing spring barley or perennial forage grass, J. Geophys. Res.-Atmos., 109, D18116, https://doi.org/10.1029/2004JD004715, 2004.

Lorenz, K. and Lal, R.: Soil Carbon Stock, in: Carbon Sequestration in Agricultural Ecosystems, Springer, Cham, 39-136, https://doi.org/10.1007/978-3-319-92318-5_2, 2018.

Manninen, N., Soinne, H., Lemola, R., Hoikkala, L., and Turtola, E.: Effects of agricultural land use on dissolved organic carbon and nitrogen in surface runoff and subsurface drainage, Sci. Total Environ., 618, 1519-1528, https://doi.org/10.1016/j.scitotenv.2017.09.319, 2018.

Minasny, B., Malone, B. P., McBratney, A. B., Angers, D. A., Arrouays, D., Chambers, A., Chaplot, V., Chen, Z.-S., Cheng, K., Das, B. S., Field, D. J., Gimona, A., Hedley, C. B., Hong, S. Y., Mandal, B., Marchant, B. P., Martin, M., McConkey, B. G., Mulder, V. L., O'Rourke, S., Richer-deForges, A. C., Odeh, I., Padarian, J., Paustian, K., Pan, G., Poggio, L., Savin, I., Stolbovoy, V., Stockmann, U., Sulaeman, Y., Tsui, C.-C., Vågen, T.-G., van Wesemael, B., and Winowiecki, L.: Soil carbon 4 per mille, Geoderma, 292, 59-86, https://doi.org/10.1016/j.geoderma.2017.01.002, 2017.

Moreau, D., Bardgett, R. D., Finlay, R. D., Jones, D. L., and Philippot, L.: A plant perspective on nitrogen cycling in the rhizosphere, Funct. Ecol., 33, 540-552, https://doi.org/10.1111/13652435.13303, 2019.

Paustian, K., Six, J., Elliott, E., and Hunt, H.: Management options for reducing $\mathrm{CO}_{2}$ emissions from agricultural soils, Biogeochemistry, 48, 147-163, https://doi.org/10.1023/A:1006271331703, 2000.

Pirinen, P., Simola, H., Aalto, J., Kaukoranta, J.-P., Karlsson, P., and Ruuhela, R.: Tilastoja Suomen ilmastosta 1981-2010, Ilmatieteen laitos, Climatological statistics of Finland 1981-2010, ISBN 978-951-697-766-2, 2012.

Rebmann, C., Kolle, O., Heinesch, B., Queck, R., Ibrom, A., and Aubinet, M.: Data acquisition and flux calculations, in: Eddy covariance, Springer, Dordrecht, 59-83, https://doi.org/10.1007/978-94-007-2351-1_3, 2012.

Regina, K., Pihlatie, M., Esala, M., and Alakukku, L.: Methane fluxes on boreal arable soils, Agr. Ecosyst. Environ., 119, 346352, https://doi.org/10.1016/j.agee.2006.08.002, 2007. 
Reinsch, T., Loges, R., Kluß, C., and Taube, F.: Effect of grassland ploughing and reseeding on $\mathrm{CO}_{2}$ emissions and soil carbon stocks, Agr. Ecosyst. Environ., 265, 374-383, https://doi.org/10.1016/j.agee.2018.06.020, 2018.

Shurpali, N. J., Hyvönen, N. P., Huttunen, J. T., Clement, R. J., Reichstein, M., Nykänen, H., Biasi, C., and Martikainen, P. J.: Cultivation of a perennial grass for bioenergy on a boreal organic soil-carbon sink or source?, GCB Bioenergy, 1, 35-50, https://doi.org/10.1111/j.1757-1707.2009.01003.x, 2009.

Singh, M., Sarkar, B., Sarkar, S., Churchman, J., Bolan, N., Mandal, S., Menon, M., Purakayastha, T. J., and Beerling, D. J.: Stabilization of soil organic carbon as influenced by clay mineralogy, Advances in Agronomy, 148, 33-84, https://doi.org/10.1016/bs.agron.2017.11.001, 2018.

Smith, P.: Land use change and soil organic carbon dynamics, Nutrient Cycling in Agroecosystems, 81, 169-178, https://doi.org/10.1007/s10705-007-9138-y, 2008.

Smith, P., Soussana, J.-F., Angers, D., Schipper, L., Chenu, C., Rasse, D. P., Batjes, N. H., van Egmond, F., McNeill, S., Kuhnert, M., Arias-Navarro, C., Olesen, J. E., Chirinda, N., Fornara, D., Wollenberg, E., Álvaro-Fuentes, J., Sanz-Cobena, A., and Klumpp, K.: How to measure, report and verify soil carbon change to realize the potential of soil carbon sequestration for atmospheric greenhouse gas removal, Global Change Biol., 26, 219-241, https://doi.org/10.1111/gcb.14815, 2020.

Soussana, J.-F., Tallec, T., and Blanfort, V.: Mitigating the greenhouse gas balance of ruminant production systems through carbon sequestration in grasslands, Animal, 4, 334-350, https://doi.org/10.1017/S1751731109990784, 2010.
Steduto, P.: Water use efficiency, in: Sustainability of Irrigated Agriculture, Springer, Dordrecht, 193-209, https://doi.org/10.1007/978-94-015-8700-6_12, 1996.

Tang, X., Li, H., Desai, A. R., Nagy, Z., Luo, J., Kolb, T. E., Olioso, A., Xu, X., Yao, L., Kutsch, W., Pilegaard, K., Köstner, B., and Ammann, C.: How is water-use efficiency of terrestrial ecosystems distributed and changing on Earth?, Sci. Rep.-UK, 4, 7483, https://doi.org/10.1038/srep07483, 2014.

Weiss, M. and Baret, F.: S2ToolBox Level 2 products: LAI, FAPAR, FCOVER, available at: https://step.esa.int/docs/extra/ATBD_ S2ToolBox_L2B_V1.1.pdf (last access: 28 Januray 2021), 2016.

Willmer, C. and Fricker, M.: Stomata, Springer, Dordrecht, The Netherlands, 1996.

Wolf, S., Eugster, W., Ammann, C., Häni, M., Zielis, S., Hiller, R., Stieger, J., Imer, D., Merbold, L., and Buchmann, N.: Contrasting response of grassland versus forest carbon and water fluxes to spring drought in Switzerland, Environ. Res. Lett., 8, 035007, https://doi.org/10.1088/1748-9326/8/3/035007, 2013.

Xu, H.-J., Wang, X.-P., Zhao, C.-Y., and Zhang, X.-X.: Responses of ecosystem water use efficiency to meteorological drought under different biomes and drought magnitudes in northern China, Agr. Forest Meteorol., 278, 107660, https://doi.org/10.1016/j.agrformet.2019.107660, 2019.

Yang, Y., Tilman, D., Furey, G., and Lehman, C.: Soil carbon sequestration accelerated by restoration of grassland biodiversity, Nat. Commun., 10, 718, https://doi.org/10.1038/s41467019-08636-w, 2019. 